\title{
Eucalyptus cinerea: Microscopic Profile, Chemical Composition of Essential Oil and its Antioxidant, Microbiological and Cytotoxic Activities
}

Matheus Saukoski Pauzer ${ }^{1}$

https://orcid.org/0000-0002-3348-0130

Thais de Oliveira Borsato ${ }^{1}$

https://orcid.org/0000-0002-1300-8162

Valter Paes de Almeida ${ }^{1}$

https://orcid.org/0000-0003-0603-8184

Vijayasankar Raman ${ }^{2}$

https://orcid.org/0000-0001-7368-9644

Bárbara Justus ${ }^{1}$

https://orcid.org/0000-0003-3943-9304

\section{Camila Bugnotto Pereira ${ }^{1}$}

https://orcid.org/0000- 0001-8210-4804

\section{Thiago Bevilacqua Flores ${ }^{3}$}

https://orcid.org/0000-0003-3015-9154
Beatriz Helena Lameiro Noronha Sales Maia ${ }^{4}$

https://orcid.org/0000-0001-5896-2892

\section{Emanuelle Kretz Meneghetti ${ }^{4}$}

https://orcid.org/0000-0001-8988-4073

Carla Cristine Kanunfre ${ }^{5}$

https://orcid.org/0000-0002-2865-3084

Josiane de Fátima Padilha de Paula ${ }^{1}$

https://orcid.org/0000-0002-2717-8867

Paulo Vitor Farago ${ }^{1}$

https://orcid.org/0000-0002-9934-4027

Jane Manfron Budel ${ }^{1 *}$

https://orcid.org/0000-0003-1873-2253

${ }^{1}$ State University of Ponta Grossa, Department of Pharmaceutical Sciences, Ponta Grossa, Paraná, Brazil; 2University of Mississippi, National Center for Natural Products Research, School of Pharmacy, Mississippi, USA; ${ }^{3}$ State University of Campinas, Department of Plant Biology, Campinas, São Paulo, Brazil; ${ }^{4}$ Federal University of Paraná, Department of Chemistry, Curitiba, Paraná, Brazil; ${ }^{5}$ State University of Ponta Grossa, Department of General Biology, Ponta Grossa, Paraná, Brazil.

Editor-in-Chief: Paulo Vitor Farago

Associate Editor: Yasmine Mendes Pupo

Received: 2020.12.07; Accepted: 2021.04.14.

*Correspondence: janemanfron@hotmail.com; Tel.: +55-41-332033124 (J.M.B.)

\section{HIGHLIGHTS}

- Eucalyptus cinerea essential oil (EO) contains 1,8-cineole as the main component.

- This EO demonstrated antioxidant and antimicrobial properties.

- This EO reduced the viability of Jurkat and Calu-3 cells and decreased DNA content.

- This EO had cell death mechanism related to apoptosis.

Abstract: Eucalyptus species possess anti-inflammatory, antifungal, antibacterial, and insecticidal properties. In this study, the chemical composition and biological activities of Eucalyptus cinerea essential oil 
(EO) and the leaf and stem anatomy were investigated. EO was extracted by Clevenger apparatus and the compounds were identified by GC/MS. The antioxidant activity was evaluated by DPPH, ABTS, and reducing phosphomolybdenum complex. Broth microdilution was used to determine antimicrobial activity. Cytotoxicity was verified against HeLa, HRT-18, and Calu-3 cells by MTT assay. The cytotoxic mechanism was studied by cell DNA content, cell cycle, and DNA fragmentation. The microscopic analyzes of the leaves and the stems were performed by light microscopy, field emission scanning electron microscopy, and energydispersive X-ray spectroscopy. The main constituent of the EO was 1,8-cineole (55.24\%). The EO showed low antioxidant and antimicrobial activities. Calu- 3 cells showed a significant reduction in viability with $\mathrm{IC}_{50}$ of $689.79 \pm 29.34 \mu \mathrm{g} / \mathrm{mL}$. EO at $1000 \mu \mathrm{g} / \mathrm{mL}$ decreased the DNA content in Jurkat cells. In general, EO increased cell percentage in sub-G0 and $S$ phases with concomitant reduction of cell percentage in G0/G1 and G2/M phases and provided DNA fragmentation of $29.73 \%$. Anatomical and micromorphological features of the leaves and stems can help in the species identification and its differentiation from other Eucalyptus species.

Keywords: anatomy; biological activity; histochemistry; microscopy; Myrtaceae; terpenoids; volatile oils. GRAPHICAL ABSTRACT

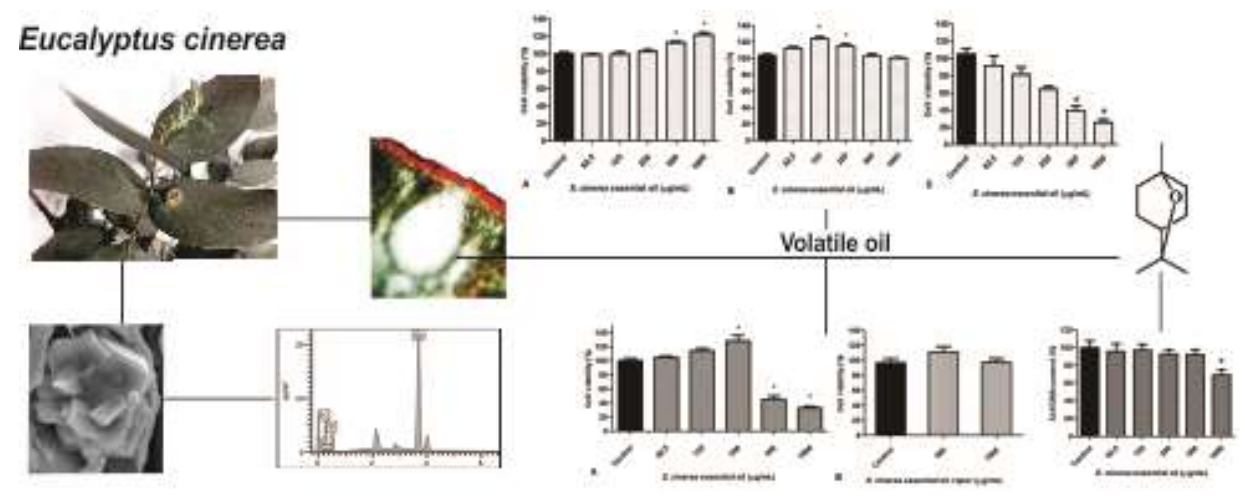

\section{INTRODUCTION}

Eucalyptus L'Hér. is one of the largest genera of Myrtaceae, represented with about 800 species. Most of these species are native to Australia and are widely cultivated throughout the world [1]. Various Eucalyptus species have particular medicinal properties and are also used in the production of paper, timber, honey, and essential oil [1,2].

Eucalytpus species have been shown to possess several medicinal properties, such as antiseptic, antioxidant, antimicrobial, acaricidal, insecticidal, and herbicidal activities, and presented a significant number of chemical compounds in the essential oils. These characteristics can be useful in the rationalization of the use of species of Eucalyptus, especially because the volatile compounds are used in agrochemical and pharmaceutical applications as well as food preservatives and flavorants [1,3]. Other therapeutic activities, such as anti-inflammatory, astringent and healing properties, have also been reported for Eucalyptus species [3-6].

Eucalyptus has become a major non-native crop in Brazil, with plantations taking up 5.63 million hectares [7], making the country the largest grower of Eucalyptus followed by India (4.3 m ha) and China (2.6 $\mathrm{m} \mathrm{ha}$ ). In Brazil, Eucalyptus cinerea F.Muell. ex Benth. is commonly called eucalipto-cinzento, eucalipto-azul and eucalipto-argentino. It is a subtropical species found in the latitudes $33^{\circ}-S$ to $36^{\circ} \mathrm{S}$ of the coastal region and central part of the Australian states of New Wales of the South and Victoria, between 100 to $1300 \mathrm{~m}$ of altitude and is well acclimatized in Brazil. It is a large tree with a rough, persistent, fibrous, and grayish bark. The leaves are sessile and measure 3.5-6.5 cm long and 3-4.5 cm wide. They are oval, with acuminate apex, rounded base, entire margin, and intense reticulate veins [1].

The essential oils (EOs) of E. cinerea have presented anti-inflammatory [8] and antimicrobial activities against Staphylococcus aureus, S. epidermidis, Escherichia coli, Pseudomonas aeruginosa, Candida albicans [9], Listeria ivanovii and Bacillus cereus [10]. EO may have potential applications in food and pharmaceutical products [10]. Considering the good yield and the high 1,8-cineole content in the EO, E. cinerea is a less exploited species [9] and could be utilized as an alternative source for 1,8-cineole production [11]. 1,8-Cineole is commonly used in the medicinal and perfumery industries [11]. 
Hence, the present work was aimed to (1) dereplicate the chemical composition of the EOs; (2) to verify the antioxidant and antimicrobial activities; (3) to characterize the cytotoxic potential of the EOs against HeLa, HRT-18, and Calu-3 cells lines in addition to confirm the cytotoxic mechanism by morphology feature changes, and (4) to investigate the anatomical and histochemical characteristics of the leaf and stem to provide botanical data to support the identification of $E$. cinerea.

\section{MATERIAL AND METHODS}

\section{Plant material}

Fresh samples of the leaves and stems of Eucalyptus cinerea were collected during November 2015 from the plants growing in Ponta Grossa (latitude 24 $18^{\prime} \mathrm{S}$ and longitude $49^{\circ} 37^{\prime} \mathrm{W}$ ), Paraná, Brazil. At least three samples of mature leaves obtained from the fourth node and below, and stem fragments collected 5$15 \mathrm{~cm}$ from the shoot tips, were prepared for extraction of essential oil and microscopy analyzes. A flowering branch of Eucalyptus cinerea was used to prepare a voucher specimen, which was stored in the Herbarium of the State University of Ponta Grossa under the number 21260 HUPG. This material was identified using relevant literature [1,12-14]. Access to the botanical material was approved by Sistema Nacional de Gestão do Patrimônio Genético e do Conhecimento Tradicional Associado (SISGEN) under code AE53EDF.

\section{Extraction of essential oil (EO) and GC-MS analysis}

For the extraction of $\mathrm{EO}$, the leaves and stems of $E$. cinerea were prepared as described by Budel and coauthors [15]. For the chemical profiling of the EO, the methods defined by Saulle and coauthors [16] were used.

\section{Antioxidant activity}

Free radical scavenging activity: 2,2-diphenyl-1-picrylhydrazyl (DPPH•) test

The scavenging activity of E. cinerea EO for DPPH• was measured as described by Yen and Wu [17], and Chen and coworkers [18]. Briefly, EOs and the positive controls (rutin and gallic acid) in methanol at 10; $15 ; 20 ; 25 \mathrm{mg} / \mathrm{mL}$ were investigated. The methanol was employed to obtain a DPPH solution $(0.1 \mathrm{mM})$. It was transferred to $20 \mu \mathrm{L}$ of the EO solution of E. cinerea as well as the positive control and blank (methanol) and $100 \mu \mathrm{L}$ of the DPPH solution in 96 well microplates. The reading was performed in a microplate reader (Biotek Instruments, Winooski, VT, USA) at $517 \mathrm{~nm}$ directly after mixing and at the end of 30 min incubation in the dark at room temperature. The antioxidant activity was determined as a percentage and calculated by the decay rate of the DPPH solution absorbance with EO after 30 min of reaction. Thus, the antioxidant activity of the EO was expressed as the half-maximal inhibitory concentration $\left(\mathrm{IC}_{50}\right)$.

\section{ABTS radical-scavenging activity}

To acquire the radical cation ABTS ${ }^{++}$, methods described by Re and coworkers [19] were performed. Then, the solution ABTS •+ was diluted in ethanol to obtain an absorbance value at \pm 0.7 to $734 \mathrm{~nm}$. The complexation between ABTS •+ and different EO concentrations $(10 ; 15 ; 20 ; 25 \mathrm{mg} / \mathrm{mL})$ was measured by decreasing absorbance at $734 \mathrm{~nm}$ after 30 min microplate reader (Molecular Devices, SpectraMax 190, Sunnyvale, USA). A rutin and gallic acid solution (10;15;20;25 mg/mL) was used as standard. The results were expressed as the concentration of antioxidant needed to suppress $50 \%$ of the oxidizing agent $\left(\mathrm{IC}_{50}\right)$.

\section{Reducing phosphomolybdenum complex}

To define the antioxidant capacity, the phosphomolybdenum complex reduction method was used as described by Prieto and coauthors [20]. An aliquot of $300 \mu \mathrm{L}$ of EO in an ethanol solution at $200 \mu \mathrm{g} / \mathrm{mL}$ was added to a test tube, along with $3 \mathrm{~mL}$ of the reagent $(4 \mathrm{mmol} / \mathrm{mL}$ ammonium molybdate, $28 \mathrm{mmol} / \mathrm{mL}$ sodium phosphate, $0.6 \mathrm{~mol} / \mathrm{L}$ sulfuric acid). Then, the tubes were hermetically sealed and transferred to a water bath at $95^{\circ} \mathrm{C}$ during $90 \mathrm{~min}$. The tube was sealed and transferred to a water bath at $95^{\circ} \mathrm{C}$ for $90 \mathrm{~min}$. After cooling, the reading was performed at $695 \mathrm{~nm}$ against a blank ( $300 \mu \mathrm{L}$ of ethanol was added $3 \mathrm{~mL}$ of reagent), using a spectrophotometer model UV/Vis Shimadzu-1601-695 nm. Ascorbic acid (Merck®) was considered as $100 \%$ antioxidant activity. 


\section{Antimicrobial activity}

\section{Broth microdilution method}

The analyzes used strains from the American Type of Culture Collection (ATCC), S. aureus ATCC ${ }^{\circledR}$ 25923, S. pyogenes ATCC $^{\circledR}$ 12228, E. coli ATCC ${ }^{\circledR} 25922$, and $P$. aeruginosa ATCC ${ }^{\circledR} 27853$. By the microdilution broth method proposed by NCCLS [21], bacteria were inoculated in BHI broth (brain heart infusion). A similar methodology was used for Candida albicans ATCC ${ }^{\circledR} 10231$, substituting the culture medium with Sabouraud. Serial dilutions $(0.013 ; 0.026 ; 0.052 ; 0.104 ; 0.208 ; 0.416 \mathrm{mg} / \mathrm{mL})$ of E. cinerea EOs were added in each well and then $10 \mu \mathrm{L}$ of each microbial inoculum were added. The microplates were covered and incubated at $35^{\circ} \mathrm{C}$ for $24 \mathrm{~h}$.

Perio GARD® $(0.12 \%$ chlorhexidine) was used as a positive control. To evaluate the viability of microorganisms in non-inhibitory concentrations, $50 \mu \mathrm{L}$ of TCC dye $(2,3,5$ triphenyl tetrazolium chloride $)$ at $1 \%$ was used and incubated at $35^{\circ} \mathrm{C}$ for $30 \mathrm{~min}$. After sowing, the Petri dishes were incubated at $37^{\circ} \mathrm{C}$ for 24 $\mathrm{h}$. The results of the antimicrobial testing were expressed as minimum inhibitory concentration (MIC) and minimum bactericidal concentration (MBC).

\section{Cytotoxic activity}

\section{Samples for cell culture tests}

According to Virador and coauthors [22], a stock solution $(300 \mathrm{mg} / \mathrm{mL})$ with propylene glycol and ethyl alcohol (1:4) was prepared as a solubilizing process. Prior to the cell experiments, this sample was diluted to final concentrations of $62.5,125,250,500,1000 \mu \mathrm{g} / \mathrm{mL}$ for E. cinerea EO and $500,1000 \mu \mathrm{g} / \mathrm{mL}$ for the vapor EO assay $[23,24]$ using culture medium.

\section{Cell and cell cultures}

HeLa (uterine cervix adenocarcinoma), HRT-18 (colon adenocarcinoma), Jurkat (T leukemia cells), and Calu-3 (lung adenocarcinoma) cells were acquired from American Type Culture Collection (Rockville, MD, USA); ATCC ${ }^{\circledR}$ CCL $244^{\mathrm{TM}}$; Cell Bank of Rio de Janeiro (Rio de Janeiro, Brazil); and ATCC ${ }^{\circledR}$ HTB- $55^{\mathrm{TM}}$, respectively. All the cultures were maintained in RPMI-1640 medium, which was added with $10 \%$ fetal bovine serum (FBS), comprising 10,000 units of penicillin and $10 \mathrm{mg}$ of streptomycin/mL. The cultures were preserved at $37{ }^{\circ} \mathrm{C}$ in a humidified $5 \% \mathrm{CO}_{2}$ incubator. These cells were subcultured every $3-4$ days. The viability of the cells surpassed $95 \%$ as determined by the trypan blue ( $0.5 \%$ trypan blue solution) dye exclusion method.

\section{In vitro cytotoxicity}

\section{Cytotoxicity of essential oil}

Calu-3 cells $\left(2.5 \times 10^{4}\right.$ cells $\left./ \mathrm{mL}\right)$, Jurkat $\left(1 \times 10^{5}\right.$ cells $\left./ \mathrm{mL}\right)$, HeLa and HRT-18 $\left(8 \times 10^{4}\right.$ cells $\left./ \mathrm{mL}\right)$ after $24 \mathrm{~h}$ plating was treated with $E$. cinerea EO in the following concentrations $62.5,125,250,500$ and $1000 \mu \mathrm{g} / \mathrm{mL}$ during $72 \mathrm{~h}$ and cytotoxicity was determined by the [3-(4,5-dimethylthiazol-2-yl)-2,5-diphenyltetrazolium bromide] (MTT) test.

\section{Cytotoxicity of vapor of essential oil}

To test the cytotoxicity of EO vapor, the Calu- 3 cells were seeded at $5 \times 10^{4}$ cells $/ \mathrm{mL}$ in 24 well plates, keeping wells devoid of cells where EO was solubilized at concentrations $500,1000 \mu \mathrm{g} / \mathrm{mL}$. The volatile components tested were volatilized at $37^{\circ} \mathrm{C}$, at the standard temperature of the $\mathrm{CO}_{2}$ greenhouse. The treatment was performed for $72 \mathrm{~h}$, and the cytotoxicity was determined by the MTT assay. The control used contained the solubilization vehicle of EO (25\% propylene glycol and $75 \%$ ethanol) that did not exceed $0.3 \%$ in culture [25].

\section{MTT assay}

MTT test was performed for investigating changes in mitochondrial/non-mitochondrial dehydrogenase activity as described by Seal and coworkers [25]. The cell lines were seeded on 24 well plates and cultured in RPMI 1640 containing $10 \%$ FBS at $37^{\circ} \mathrm{C}$ and $5 \% \mathrm{CO}_{2}$ for $24 \mathrm{~h}$. Then, different concentrations of EO were 
added. After incubation and proceeding to the end of the experiment, the supernatant was removed, and 0.5 $\mathrm{mg} / \mathrm{mL}$ of MTT solution was added to each well. Water-insoluble dark blue formazan crystals formed in viable cells were solubilized in DMSO. The spectrophotometric absorbance was read at $550 \mathrm{~nm}$ in Biotek, $\mu$ Quant $\AA$ plate reader. To determine survived cells, the absorbance values acquired for the treated and untreated cells were considered. The cytotoxicity of EO was expressed as the concentration of the sample, which inhibited $50 \%$ of cell growth $\left(\mathrm{IC}_{50}\right)$ and was calculated by Probit regression using the Least Squares method.

\section{Analysis of mechanisms involved in the cytotoxic activity}

\section{Analysis of cell DNA content: Propidium iodide (PI)}

Propidium iodide $(\mathrm{PI})$ assay was used to analyze the DNA content as described by Dengler and coauthors [26] with some modifications. Jurkat cells were seeded $\left(1 \times 10^{5} \mathrm{cells} / \mathrm{mL}\right)$ on 24 -well plates. After $24 \mathrm{~h}$, different concentrations of $E$. cinerea EO $(62.5 ; 125 ; 250 ; 500 ; 1000 \mu \mathrm{g} / \mathrm{mL})$ were added. After $72 \mathrm{~h}$, aliquots of $50 \mu \mathrm{L}$, corresponding to a cell concentration of $4 \times 10^{4}$ cells $/ \mathrm{mL}$, were transported to a black 96well plate. Then, $150 \mu \mathrm{L}$ of a solution containing $100 \mu \mathrm{g} / \mathrm{mL}$ PI, $0.2 \%(\mathrm{v} / \mathrm{v})$ Triton X-100 and $0.2 \%(\mathrm{v} / \mathrm{v})$ sodium citrate was added. After an incubation period of $24 \mathrm{~h}$ at room temperature, the fluorescence (FU) was measured using a Cytofluor $\mathrm{H} 4000$ microplate reader (excitation at $525 \mathrm{~nm}$ and emission at $617 \mathrm{~nm}$ ) to quantify the amount of attached viable cells.

\section{Cell cycle and DNA fragmentation assay}

According to Crissman and Steinkamp [27], Jurkat cells $\left(1 \times 10^{5}\right.$ cells $\left./ \mathrm{mL}\right)$ were seeded on 24 well plates and cultured in RPMI 1640 containing $10 \% \mathrm{FBS}$ at $37^{\circ} \mathrm{C}$ and $5 \% \mathrm{CO}_{2}$ for $24 \mathrm{~h}$. The cells were treated with different concentrations of $E$. cinerea $E O(125,250$ and $500 \mu \mathrm{g} / \mathrm{mL})$ for $72 \mathrm{~h}$. The cells were centrifuged at $300 \mathrm{~g}$ for $7 \mathrm{~min}$. The pellets were washed with PBS buffer $(1 \mathrm{~mL})$, centrifuged, resuspended in $400 \mu \mathrm{L}$ of PSSI buffer $(1.4 \mu \mathrm{L}$ of $1 \%$ Triton X - 100; $20 \mu \mathrm{L}$ of $20 \mathrm{mg} / \mathrm{mL}$ RNAse; $60 \mu \mathrm{L}$ of $2 \mathrm{mg} / \mathrm{mL}$ propidium iodide and $8.520 \mu \mathrm{L}$ of PBS). Each sample was incubated for $15 \mathrm{~min}$ at $37^{\circ} \mathrm{C}$. The analysis was performed on the flow cytometer (FACsCANTO II from Becton \& Dickinson, San Jose, CA, USA). The results corresponding to 30,000 events per sample were obtained and processed in the DIVA program (Becton \& Dickinson) and expressed as percentage of cells in different phases of the cell cycle and fragmented DNA.

\section{Microscopic procedure}

The methods used for plant material preparation, light microscopy (LM), scanning electron microscopy (SEM), Energy-dispersive X-ray spectroscopy (EDS), and histochemical tests were fully detailed in a previous paper by Machado and coauthors [28].

\section{Statistical analysis}

Statistical analysis was performed by ANOVA and Tukey's posthoc test. The results were expressed as mean \pm standard error of the mean (SEM). A value of $p<0.05$ was considered indicative of significance. All the tests were carried out using Graph Pad Prism 5.01 software.

\section{RESULTS AND DISCUSSION}

\section{Yield and Chemical Composition of Essential Oil (EO)}

The EO yield of $E$. cinerea was $5.4 \%(\mathrm{v} / \mathrm{w})$. This species produces the highest quantity of EOs in the genus. Variations in the EO yield have been reported, such as $2.48 \%$ EO from the plants cultivated in Argentina [29], 4.5\% for leaves and $0.5 \%$ for stems from the plants cultivated in Egypt [30] and $6.07 \%$ for those sourced from Paraná state in Brazil [9]. Eucalyptus cinerea EO frequently contains more than $80 \%$ of 1,8-cineole [2] as the main component. Comparing the studies from Argentina, Brazil and Tunisia, the presence of 1,8-cineole was between $56.9-88.5 \%$ [2]. However, a low concentration of 1.8 -cineole $(5.2 \%)$ was found in the EO of leaves from Congo.

In the present work, the monoterpene 1,8-cineole (55.24\%) was identified as the major compound in the $\mathrm{EO}$ of $E$. cinerea (Table 1). Also known as eucalyptol, this monoterpene has medicinal properties and can be used as an anesthetic and antiseptic [31]. 1,8-Cineole is also used for the treatment of chronic bronchitis, sinusitis and respiratory infections, and for stimulating expectoration. This compound also has anti- 
inflammatory action in patients with asthmatic bronchitis and presents more potential antimicrobial activity than citronellal and caryophyllene [32,33]. 1,8-Cineole has been identified as the major compound (22-83\%) in several species of Eucalyptus [2].

Several factors can influence Eucalyptus EO production, including genetic variability, leaf age, environmental conditions, plantation management, part of the plant used for EO extraction, the extraction process, and analysis method [2,16,34]. According to Bugarin and coauthors [35], there is great variation in the composition of volatile compounds for the same species of Eucalyptus obtained from different geographic origins. The chemistry of the EOs must be better studied because biological activities are highly dependent on the EO chemical composition [2].

Silvestre and coworkers [36] have observed that young leaves tend to have a lower 1,8-cineole content. However, in Argentina, 90.7\% of 1,8-cineole was found in fresh and young leaves of $E$. globulus subsp. bicostata (Maiden, Blakely \& Simmonds) J. B. Kirkp., obtained in the first hour of distillation [37]. In that sense, the amount of 1,8-cineole is related to leaf age and the time of hydrodistillation. In the present study, adult leaves and stems were used for the extraction, and the EO was collected after $3 \mathrm{~h}$ of hydrodistillation.

a-terpinyl acetate was the second major compound in the EO of E. cinerea (21.64\%). It is mainly used for medicinal and pharmaceutical purposes [38]. The monoterpenoids 1,8-cineole and $\alpha$-terpinyl acetate in Eucalyptus species have important antimicrobial activities and are used as biomarkers for the plants' resistance against eucalyptus rust disease [39].

Table 1. Chemical composition of Eucalyptus cinerea essential oil.

\begin{tabular}{lcccc}
\hline Volatile compounds & RI cal. ${ }^{2}$ & RI lit. $^{1}$ & Peak area (\%) & Identification \\
\hline a-pinene & 932 & 932 & 7.94 & RI, MS $^{3}$ \\
1,8-Cineole ( & 1033 & 1026 & 55.24 & RI, MS \\
& 1192 & 1180 & 6.45 & RI, MS \\
Furfuryl ketone & 1351 & 1346 & 21.64 & RI, MS \\
a-Terpinil acetate & & & &
\end{tabular}

${ }^{1}$ Retention index literature from Adams [40]. ${ }^{2}$ Calculated retention index. ${ }^{3}$ Mass spectra from NIST02 library.

\section{Antimicrobial activity}

According to Bhavanani and Ballow [41], approximately $60 \%$ of EOs present antifungal activity, being able to be superior to the commercial synthetic antifungal products [42], and about $35 \%$ of the oils exhibit antibacterial activity. EOs of Eucalyptus are active against Gram-positive and Gram-negative bacteria as well as several fungal species [2]. Barbosa and coauthors [2] affirmed that $S$. aureus and $C$. albicans exhibited high sensitivity and $P$. aeruginosa most resistant to the EOs of Eucalyptus species.

EOs of $E$. cinerea presented values of MIC and MBC between $0.104 \mathrm{mg} / \mathrm{mL}$ to $0.416 \mathrm{mg} / \mathrm{mL}$ (Table 2). The results showed that EO of $E$. cinerea has antimicrobial activity more pronounced in the Gram-positive bacteria. Different species of Eucalyptus, such as E. oleosa F.Muell. ex Miq., E. robusta Sm., E. camaldulensis Dehnh., E. citriodora Hook., E. globulus Labill. and E. saligna Sm. also presented relevant activities against Gram-positive bacteria $[4,43]$. The resistance of Gram-negative bacteria to the action of the EO is due to the fact that its cell wall is coated by an outer membrane limiting the diffusion of hydrophobic compounds $[44,45]$.

Silva and coauthors [46] have also investigated the antimicrobial activity of EO of different parts of $E$. cinerea, obtained during different seasons of the year, by the broth microdilution method and disk diffusion test. The results showed that the EO was active against $S$. aureus, $S$. pyogenes, $P$. aeruginosa and $C$. albicans, with MIC values of $0.780 \mathrm{mg} / \mathrm{mL} ; 0.390 \mathrm{mg} / \mathrm{mL} ; 3.120 \mathrm{mg} / \mathrm{mL}$ and $1.560 \mathrm{mg} / \mathrm{mL}$, respectively. In the same study, the EO of E. cinerea showed antimicrobial activity by the disc diffusion test while the major compound 1,8-cineole showed inferior activity to EOs obtained in different seasons of the year, with MIC values between 12.50 and $50.00 \mathrm{mg} / \mathrm{mL}$.

EOs of Eucalyptus camaldulensis and E. tereticornis Sm. showed potent antibacterial activities, inhibiting almost all of the bacteria tested, including $P$. aeruginosa. Other species in the genus, such as Eucalyptus robusta, E. alba Reinw. ex Blume, E. citriodora, E. deglupta Blume, E. globulus and E. saligna, also showed this activity [4].

Studies with EO of E. cinerea confirmed the antimicrobial activity of this species. However, the results found were different from those reported in the literature which can be explained by differences in the sensitivity of the strains of a given microorganism to a particular antimicrobial and differences in the concentration of active compounds in the EO. According to Hammer and coauthors [47], the oils have 
hydrophobic characteristics that make it impossible to mix homogeneously with the culture medium, resulting in differences in microbial growth and different MIC values. In addition to the previously reported factors, characteristics such as plant age, seasonality, water availability, temperature, soil nutrients, altitude and UV radiation also tend to influence the chemical composition of EOs and affecting their antimicrobial properties $[2,48]$.

Table 2. Antimicrobial activities of Eucalyptus cinerea essential oil

\begin{tabular}{lcc}
\hline Microorganisms & MIC $(\mu \mathbf{g} / \mathbf{m L})^{1}$ & $\mathbf{M B C}(\mu \mathbf{g} / \mathbf{m L})^{2}$ \\
\hline Escherichia coli ATCC $\AA$ 25922 & 0.416 & 0.416 \\
Candida albicans ATCC 10231 & 0.104 & 0.104 \\
Staphylococcus aureus ATCC 25923 & 0.208 & 0.208 \\
Staphylococcus pyogenes ATCC® 12228 & 0.104 & 0.104 \\
Pseudomonas aeruginosa ATCC® 27853 & 0.416 & $\mathrm{Nl}^{3}$ \\
Chlorhexidine & 1.2 & 1.2 \\
\hline
\end{tabular}

${ }^{1}$ Minimum inhibitory concentration. ${ }^{2}$ Minimum bactericidal concentration. ${ }^{3}$ No inhibition.

\section{Antioxidant activity}

The antioxidant activities of EOs of E. cinerea are shown in Table 3. In the free radical DPPH $(2,2$ diphenyl-1-picryl-hydrazylhydrate) method, EO of $E$. cinerea $(10-25 \mathrm{mg} / \mathrm{mL})$ presented activity between $20.47 \% \pm 3.18$ and $7.34 \% \pm 2.95$, with statistically significant differences in relation to rutin and gallic acid standards. The low antioxidant activity found in our study was also reported in EOs of E. radiata A.Cunn. ex DC. by means of the DPPH assay ( $\left.\mathrm{IC}_{50}>10,000 \mathrm{mg} / \mathrm{L}\right)$ [49]. However, Döll-Boscardin and coauthors [6] found a high value of $\mathrm{IC}_{50}(3209.66 \mu \mathrm{g} / \mathrm{mL}$ to scavenge $50 \%$ of DPPH radicals) of EO of $E$. benthamii Maiden \& Cambage by the DPPH assay. However, Salem and coauthors [50] checked the best results in EO of $E$. camaldulensis subsp. camaldulensis and E. gomphocephala A.Cunn. ex DC. with values of $70 \pm 3.13 \%$, $50 \pm 3.34 \%$ and $84 \pm 4.64 \%$, respectively.

In the phosphomolybdenum complex reduction assay, EO of E. cinerea (23.43\%) presented a statistically significant difference in relation to the rutin $(83.76 \%)$ and gallic acid $(60.28 \%)$ standards. EO of E. benthamii presented a higher antioxidant activity $(43.15 \% \pm 1.08)$, with a statistically significant difference in relation to the ascorbic acid standard (100\%) [6].

In the ABTS-radical scavenging activity, EO of $E$. cinerea presented $25.48 \%$ of antioxidant activity with statistical differences in relation to rutin (97.91\%) and gallic acid (99.66\%). Marzoug and coauthors [43] found a better antioxidant activity in EO of the leaves and stem of $E$. oleosa F.Muell. ex Miq. with $\mathrm{IC}_{50}$ values 13.0 $\pm 0.6 \mathrm{mg} / \mathrm{L}$ and $43.5 \pm 1.4 \mathrm{mg} / \mathrm{L}$, respectively. In the present study, medium antioxidant activity was found in the ABTS assay $\left(\mathrm{IC}_{50}=484.3 \pm 17.3 \mathrm{mg} / \mathrm{L}\right)$.

In general, EO of $E$. cinerea showed a low antioxidant action in the assays performed. According to Ruberto and Baratta [51], EOs with high levels of monoterpenoids are often inefficient as antioxidants. This could explain the reduced antioxidant activity of EO of E. cinerea, which contains monoterpenoids 1,8-cineole and $\alpha$-pinene as major compounds.

Table 3. Antioxidant activities of Eucalyptus cinerea essential oil.

\begin{tabular}{lccc}
\hline Sample & $\begin{array}{c}\text { DPPH }^{3} \text { AA }^{2} \\
(\% \pm \text { SEM) }\end{array}$ & $\begin{array}{c}\text { FOSFOMOLYBDENIUM }^{3} \\
\text { AA }^{2}(\% \pm \text { SEM) }\end{array}$ & $\begin{array}{c}\text { ABTS }^{3} \\
\text { AA }^{2}(\% \pm \text { SEM) }\end{array}$ \\
\hline EO E. cinerea & $20.47 \pm 3.18^{1}$ & $23.43 \pm 0.27$ & $25.48 \pm 2.62^{1}$ \\
Rutin & $99.50 \pm 0.36$ & $83.76 \pm 0.97$ & $97.91 \pm 0.82$ \\
Gallic acid & $99.93 \pm 0.06$ & $60.28 \pm 0.70$ & $99.66 \pm 0.37$ \\
\hline
\end{tabular}

${ }^{1} \mathrm{EO}(25 \mathrm{mg} / \mathrm{mL}) .{ }^{2}$ antioxidant activity (AA) in percentage \pm standard error of the mean. ${ }^{3}$ statistically different results $(p<0.05)$.

\section{In-vitro cytotoxicity tests}

\section{MTT assay with HeLa, HRT-18, Jurkat cells}

The cell viability after treatment with EO of $E$. cinerea is related to the concentrations described in Material and methods section (Figure 1). The control consists of the propyleneglycol in ethanol (1:4), which did not exceed $0.3 \%$ in culture. EO of $E$. cinerea showed no cytotoxicity up to the concentration of 1000 
$\mu \mathrm{g} / \mathrm{mL}$ against HeLa and HRT cells (Figure 1). Several species of Eucalyptus present cytotoxic activity as reported in EOs of E. sideroxylon A.Cunn. ex Woolls and E. torquata Luehm. against human hepatocellular carcinoma cell line (HEP-G2) and breast adenocarcinoma cell line (MCF-7) [52]. Döll-Boscardin and coauthors [5] showed that $E O$ from the young leaves of $E$. benthamii exhibited cytotoxicity against HeLa cells at $300 \mu \mathrm{g} / \mathrm{mL}$ with $\mathrm{IC}_{50}$ of $120.57 \mu \mathrm{g} / \mathrm{mL}$.

Although no cytotoxicity has been observed with EO of E. cinerea, the literature reports that HeLa cells are responsive to treatments performed with EOs of different species [53,54]. Likewise, EO of E. cinerea was not cytotoxic to HRT-18 cells. However, Murata and coauthors [55] reported antitumor activity for 1,8-cineole in different colon cancer cell lines (HCT-16 and RKO). Jurkat cells showed greater susceptibility to EO of $E$. cinerea with $\mathrm{IC}_{50}$ of $391.43 \pm 34.57 \mu \mathrm{g} / \mathrm{mL}$ (Table 3). The cytotoxic effect in cells of leukemic origin (HL-60) treated with $\mathrm{EO}$ of E. camaldulensis $\left(\mathrm{IC}_{50}\right.$ of $\left.42.1 \mu \mathrm{g} / \mathrm{mL}\right)$ [56]. EO of Baccharis milleflora DC. showed cytotoxicity after $24 \mathrm{~h}$ of treatment, compared to Jurkat, $\mathrm{HL}-60$ and Raji cells with $\mathrm{IC}_{50}$ values of $42.91,23.06$ and $39.15 \mu \mathrm{g} / \mathrm{mL}$, respectively [57].

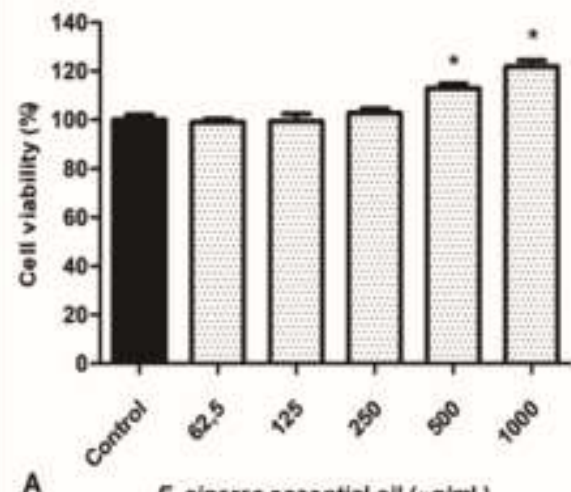

A

E. cinerea essential oil ( $\mu \mathrm{g} / \mathrm{mL})$

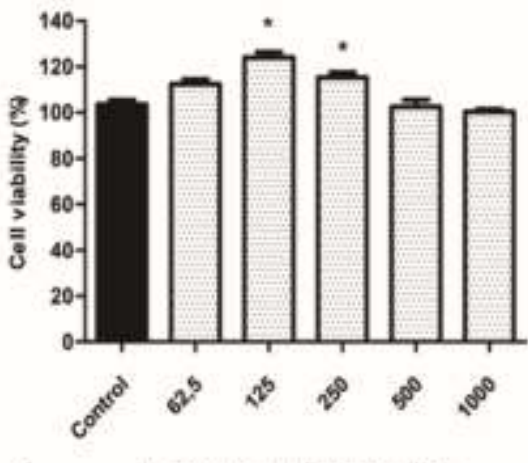

B

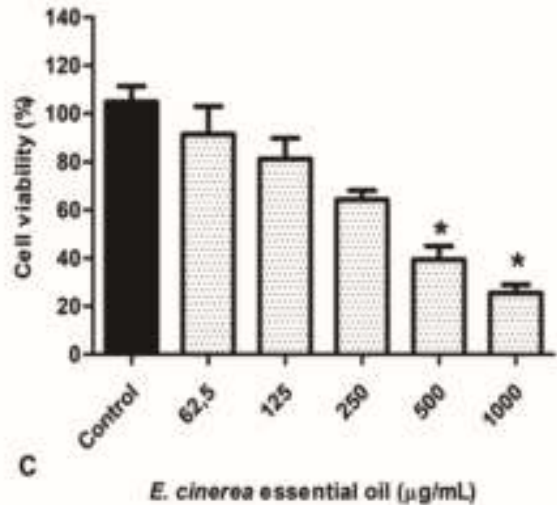

E. cinerea essential oil $(\mu \mathrm{g} / \mathrm{mL})$

Figure 1. Cytotoxicity of EOs of Eucalyptus cinerea by MTT assay in relation to (A) HeLa, (B) HRT-18, (C) Jurkat cell lines after $72 \mathrm{~h}$ of treatment. The results are shown as mean \pm SEM $(n=24)$. The symbol * represents a value of $p<$ 0.05 , which is considered significant compared to the control.

\section{MTT assay with Calu-3 cells}

Calu-3 cell viability after $72 \mathrm{~h}$ treatment with EOs and vapor of EO of E. cinerea (Figure 2). The control consisted of the propyleneglycol in ethanol (1:4), which did not exceed $0.3 \%$ in culture. The results of the cell viability experiments were expressed as $\mathrm{IC}_{50}$ (Table 4).

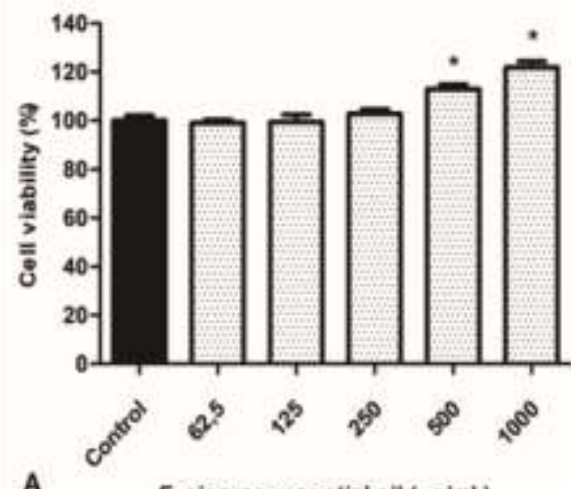

E. cinerea essential oll ( $\mu \mathrm{g} / \mathrm{mL})$

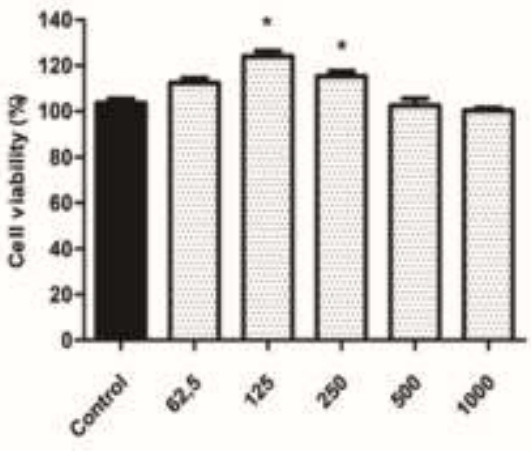

B

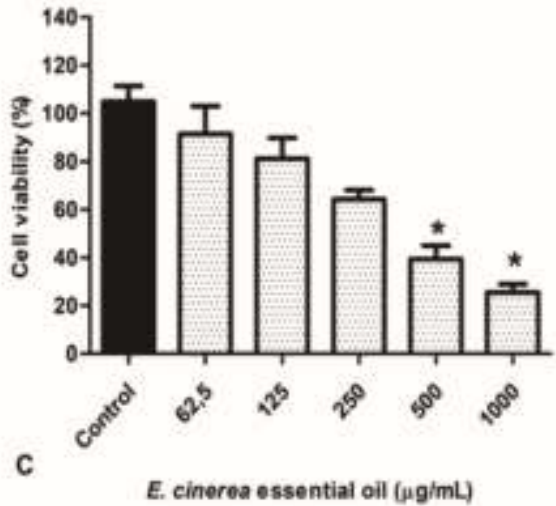

E. cinerea essential oil $(\mu \mathrm{g} / \mathrm{mL})$

Figure 2. Cytotoxicity of Eucalyptus cinerea essential oil by MTT assay in relation to (A) Calu-3 cell line after $72 \mathrm{~h}$ of treatment with essential oil, (B) Calu-3 cell line after $72 \mathrm{~h}$ of treatment with essential oil vapor. The results are shown as mean \pm SEM $(n=24)$. The symbol * represents a value of $p<0.05$, which was considered significant compared to the control.

The EOs of Eucalyptus species are extensively employed in aromatherapy, especially in treating respiratory system disorders. According to Seal and coauthors [25], vaporization with EOs induces the killing of tumor cells in culture assays. However, the mechanism of transport of inhaled volatile constituents to the lungs and their effects have not yet been fully understood. In accordance with Selvarani and James [58], the 
vapor phase of EO has the advantage of practicality and less toxic potential compared to the liquid phase. In this context, Calu-3 cells are advantageous in the investigation and development of inhalable drugs [59]. Reports on the biological activities of the vapor phase of EOs are still scarce. However, for the microbiological evaluation, Laird and Phillips [60] showed that vapor of EO has antibacterial effects against E. coli, Listeria monocytogenes, Salmonella enteritidis, $S$. aureus and $P$. aeruginosa.

According to Jakiemiu [61], monoterpenoids are more volatile than the other terpenes because they have low molecular mass, but this feature was not observed for 1,8-cineole. In the present study, essential oil vapor did not exhibit cytotoxicity in Calu-3 cells at the concentrations tested. EO of $E$. cinerea showed a significant reduction in cell viability from $500 \mu \mathrm{g} / \mathrm{mL}$ with an $\mathrm{IC}_{50}$ of $689.79 \pm 29.34 \mu \mathrm{g} / \mathrm{mL}$. Several studies have demonstrated the cytotoxic action of EOs in bronchoalveolar lung carcinoma cell lines. Manjamalai and coauthors [63] reported effects of the EO of Tridax procumbens $\mathrm{L}$. in preventing lung metastasis by B16F-10 cell line in C57BL/6 mice.

Table 4. Cytotoxicity of Eucalyptus cinerea essential oil by MTT assay in relation to tumor cell lines after $72 \mathrm{~h}$.

\begin{tabular}{lc}
\hline Cell line & $\mathbf{I C}_{50}(\mu \mathrm{g} / \mathbf{m L}) \mathbf{7 2} \mathbf{~ h}$ \\
\hline Hela & $>1000^{3}$ \\
Calu-3 & $689.79 \pm 29.34$ \\
Calu-3 $^{2}$ & $>5000^{3}$ \\
HRT-18 & $>1000^{3}$ \\
Jurkat & $391.43 \pm 34.57$ \\
\hline
\end{tabular}

$\mathrm{IC}_{50}$ : concentration that reduces mitochondrial activity by $50 \%$. The results are shown as mean \pm SEM $(n=24)$. The $\mathrm{IC}_{50}$ values were calculated by the Least Squares method. ${ }^{1} \mathrm{Calu}-3$ cells treated with essential oil. ${ }^{2} \mathrm{Calu}-3$ cells treated with essential oil vapor. ${ }^{3}$ Estimated values according to cytotoxicity assays.

\section{Analysis of mechanisms involved in the cytotoxic activity}

\section{Analysis of cell DNA content: Propidium iodide (PI)}

The results of the proliferation of Jurkat tumor cells are shown in Figure 3. A significant reduction in DNA content was observed in $1000 \mu \mathrm{g} / \mathrm{mL}$ compared to the control. In the other concentrations tested, no reductions in DNA contents were detected. Pereira and coauthors [57] evaluated $B$. milleflora EO with Jurkat, Raji and HL-60 cells and reported a decrease in DNA content for all tested tumor cell lines. Döll-Boscardin and coauthors [5] reported that EO of $E$. benthamii demonstrated a statistically significant reduction in DNA content compared to vincristine used as a positive control.

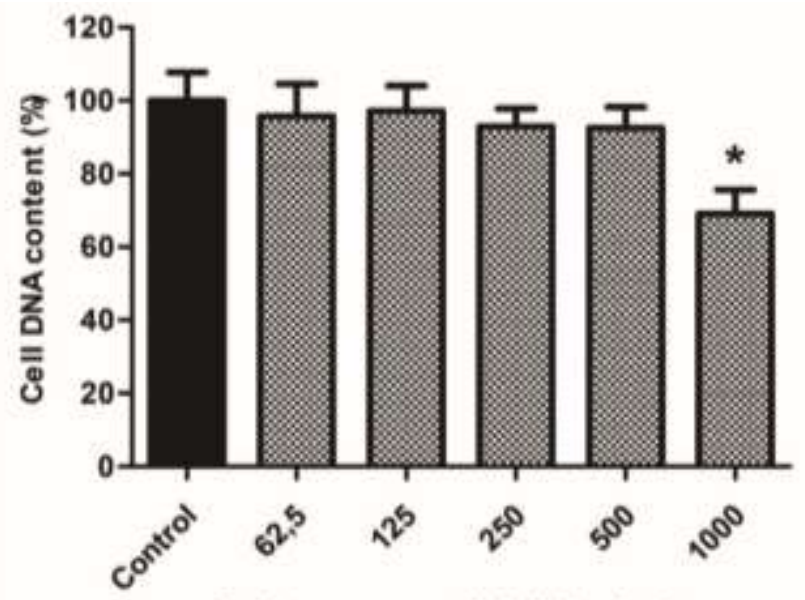

E. cinerea essential oil ( $\mu \mathrm{g} / \mathrm{mL})$

Figure 3. Determination of cell proliferation using propidium iodide by measuring the DNA content of Jurkat cells treated with Eucalyptus cinerea essential oil $(62.5 ; 125 ; 250 ; 500 ; 1000 \mu \mathrm{g} / \mathrm{mL})$ and control for $72 \mathrm{~h}$. The results are shown as mean \pm SEM $(n=16)$. The symbol * represents $p<0.05$, which was considered highly significant compared to the control $(100 \%)$.

\section{Cell cycle and DNA fragmentation assay}

Table 5 displays the effect of EO of $E$. cinerea on the cell cycle progression of Jurkat cells. At $500 \mu \mathrm{g} / \mathrm{mL}$, statistically significant results were detected after $72 \mathrm{~h}$ in Sub G0, G0/G1 and G2M phases. In the S phase, 
EO did not present significant differences with the control. Besides that, no changes were observed in the cell cycle at 125 and $250 \mu \mathrm{g} / \mathrm{mL}$. EO of E. cinerea produced an increase in the percentage of cells in the sub G0 and $S$ phases with concomitant reduction of the cell percentage in the G0/G1 and G2/M phases. According to Döll-Boscardin and coauthors [5], changes in the cell cycle in the $S, G 2 / M$ and $G 0 / G_{1}$ phases revealing of cycle block/stop. EO at $500 \mu \mathrm{g} / \mathrm{mL}$ also induced cell fragmentation, characterized by an increase in the sub G0 population. This effect was also observed in DNA fragmentation analysis (Table 6). Grivicich and coauthors [64] affirmed that the presence of fragmented DNA is one of the alterations that precede cell death by apoptosis. To date, no studies reporting the action of $E$. cinerea $\mathrm{EO}$ on the cell cycle available in the literature, although numerous reports describing the action of EOs of various other species have been published.

Table 5. Distribution of Jurkat cells in cell cycle after treatment with Eucalyptus cinerea essential oil

\begin{tabular}{|c|c|c|c|c|c|}
\hline \multirow{2}{*}{ Treatment } & \multirow{2}{*}{$\mu \mathrm{g} / \mathrm{mL}$} & \multicolumn{4}{|c|}{ Cell cycle distribution (\%) } \\
\hline & & Sub G01 & G0/G1 & $\mathbf{s}$ & G2/M \\
\hline \multirow[t]{2}{*}{ Control } & & $4.03 \pm 0.30$ & $62.01 \pm 3.27$ & & $41 \pm 1.79$ \\
\hline & 125 & $3.55 \pm 0.31$ & $59.59 \pm 2.32$ & & $87 \pm 1.78$ \\
\hline \multirow[t]{2}{*}{ Essential oil } & 250 & $3.87 \pm 0.53$ & $58.33 \pm 1.27$ & & $13 \pm 1.34$ \\
\hline & 500 & $6.28 \pm 1.30^{2}$ & $50.87 \pm 3.48^{2}$ & & $32 \pm 1.20^{2}$ \\
\hline
\end{tabular}

Propylene glycol and ethyl alcohol (1:4) was used as a negative control. The results are expressed as mean \pm SEM $(n=$ 4). 'Sub G0 represents the percentage of cells with fragmented DNA in relation to the total events (30.000) analyzed. 2Statistical differences $(p<0.05)$ when one-way ANOVA followed by Tukey's post-hoc test was applied in relation to the control during $72 \mathrm{~h}$ of the treatment.

The percentage of DNA fragmentation along with cell cycle analysis was performed for Jurkat cells (Table 6). As described in the cell cycle assay, EO of E. cinerea at $500 \mu \mathrm{g} / \mathrm{mL}$ caused DNA fragmentation with a statistically significant difference to the control. Considering the results, E. cinerea EO probably lead to a death mechanism associated with apoptosis. Wong [65] opines that apoptosis is a superior mechanism for feasible therapeutic interventions on the pathophysiology of cancer.

Considering the mechanism of action, several studies have been reported that EOs inducing cell death $[66,67]$. Apoptosis death is a process also observed for several antitumor agents $[64,68]$. Eugenol, a common volatile compound of several EOs, displayed apoptosis in HL-60 cells, including DNA fragmentation and formation of DNA ladders in agarose gel electrophoresis.

Justus and coauthors [68] analyzed Lavandula dentata L. EO on Calu-3 lung cancer cells in both vapor and liquid phases and reported a significant reduction of cell viability by reaching $84 \%$ cytotoxicity in vapor phase, showing a time-dependent profile. Although both necrosis and apoptosis mechanisms were involved in Calu-3 cell death, necrosis seemed to be the dominant cell death pathway.

Table 6. DNA fragmentation after treatment with Eucalyptus cinerea essential oil.

\begin{tabular}{lc}
\hline Treatment & Fragmentation (\%) \\
\hline Control & $16.39 \pm 2.14$ \\
$125 \mu \mathrm{g} / \mathrm{mL}$ & $18.60 \pm 1.09$ \\
$250 \mu \mathrm{g} / \mathrm{mL}$ & $19.46 \pm 3.80$ \\
$500 \mu \mathrm{g} / \mathrm{mL}$ & $29.73 \pm 2.171$ \\
\hline
\end{tabular}

Results are expressed as mean and standard deviation (SD) of $n=4$ with analysis of 30,000 events per sample. ${ }^{1}$ Statistical differences $(p<0.05)$ when one-way ANOVA followed by Tukey's post-hoc test was applied in relation to the control during $72 \mathrm{~h}$ of the treatment.

\section{Anatomical analysis}

The leaves of Eucalyptus cinerea (Figure 4 A, B), in frontal view, show epidermal cells with straight and thin anticlinal walls on both sides (Figure 4 C, D). The leaves are amphistomatic, and two types of stomata, anomocytic and actinocytic, are observed (Figure $4 \mathrm{C}, \mathrm{D}$ ). The stomata measure an average of $23 \mu \mathrm{m}$ in length. Both amphistomatic [16,70] and hypostomatic [70] leaves were met in the genus, while amphistomatic 
leaves were more frequent. Anomocytic stomata are typical in Eucalyptus [16,69,71] whereas, actinocytic stomata were commonly found in other genera of Myrtaceae [72].

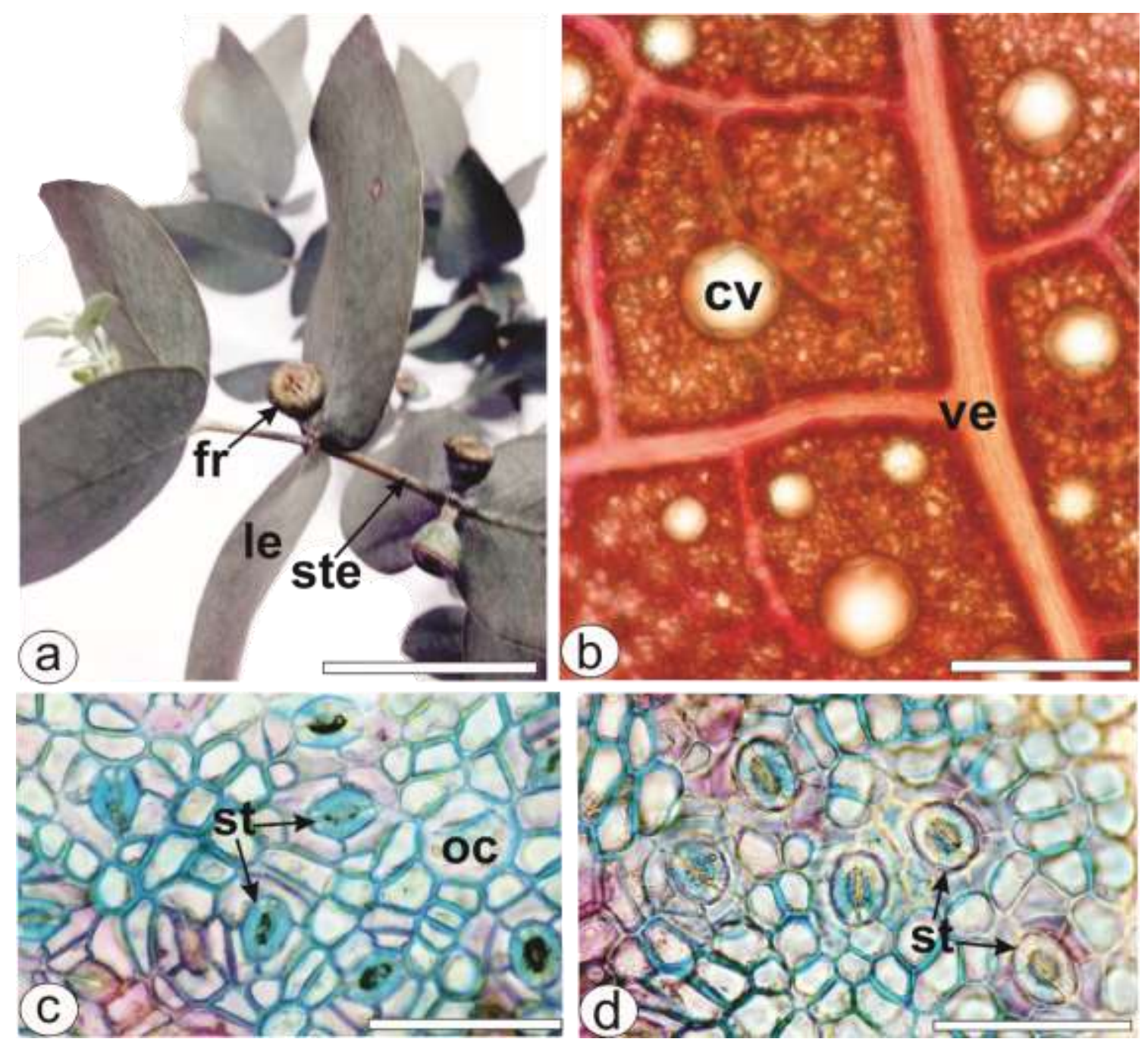

Figure 4. Morpho-anatomy of Eucalyptus cinerea. [Light microscopy; stained in safranin (b) and Astra blue (c, d)]. a. Photo of twigs with fruits. $b$ and d. Lower epidermis. c. Upper epidermis. [cv- secretory cavities, fr- fruits, le- leaves, ocoverlying cells, st- stomata, ste- stem, ve- veins. Scale bar: $a=5 \mathrm{~cm} ; b=200 \mu \mathrm{m} ; c, d=50 \mu \mathrm{m}$.

E. cinerea leaf shows a pair of overlying cells of secretory cavities at the same level as the stomata and other epidermal cells (Figure $4 \mathrm{C}$ ). These cells are also found in many other species of Eucalyptus [69,71]. Although the overlying cells are frequent in the genus, variations in the number of cells can be found; for example, the overlying cells are made up of up to four cells in E. pyrocarpa L.A.S.Johnson \& Blaxell [71].

The leaves of $E$. cinerea, in cross-section, show uniseriate epidermis with smooth and thick cuticle and papillae (Figure $5 \mathrm{~A}, \mathrm{~B}$ ). Thick cuticle and papillae were also observed in many species of Eucalyptus $[16,69,71]$. However, papillae were not found in E. platypus Hook.f., E. spathulata Hook. and E. viridis F.Muell. ex R.T.Baker [72].

The mesophyll is isobilateral and is formed by about three layers of palisade parenchyma on both sides and two layers of spongy parenchyma. Small bicollateral vascular bundles surrounded by parenchymatous sheath are immersed in the mesophyll (Figure $5 \mathrm{~A}$ ). Druses and prismatic crystals are found in the mesophyll. Isobilateral mesophyll is common in Eucalyptus [16,69]. However, a dorsiventral organization can be met in E. globulus subsp. bicostata (Maiden, Blakely \& Simmonds) J.B.Kirkp. [70], E. grandis W.Hill, E. pilularis Sm., and E. resinifera Sm. [71].

In the present study, secretory cavities (Figure 4 B) are observed in the mesophyll, especially in the subepidermal region on both sides of the leaves (Figure $5 \mathrm{~B}$ ). Secretory cavities are common in the genus $[16,69,71]$. In Myrtaceae, they are usually found in the palisade parenchyma, typically in contact with the adaxial epidermis, but sometimes they can occur in both adaxial and abaxial palisades [72]. 
The midrib, in cross-section, is slightly convex on both sides (Figure $5 \mathrm{C}$ ). This shape was observed in E. pyrocarpa [71], E. badjensis Beuzev. \& Welch and E. benthamii Maiden \& Cambage [69]. Flat-convex shape has been described in several species of Eucalyptus, such as E. grandis, E. resinifera, E. saligna and E. urophylla S.T.Blake [69,71]. Migacz and coauthors [69] reported that the midrib shape and the vascularization pattern may help in the differentiation of Eucalyptus species.

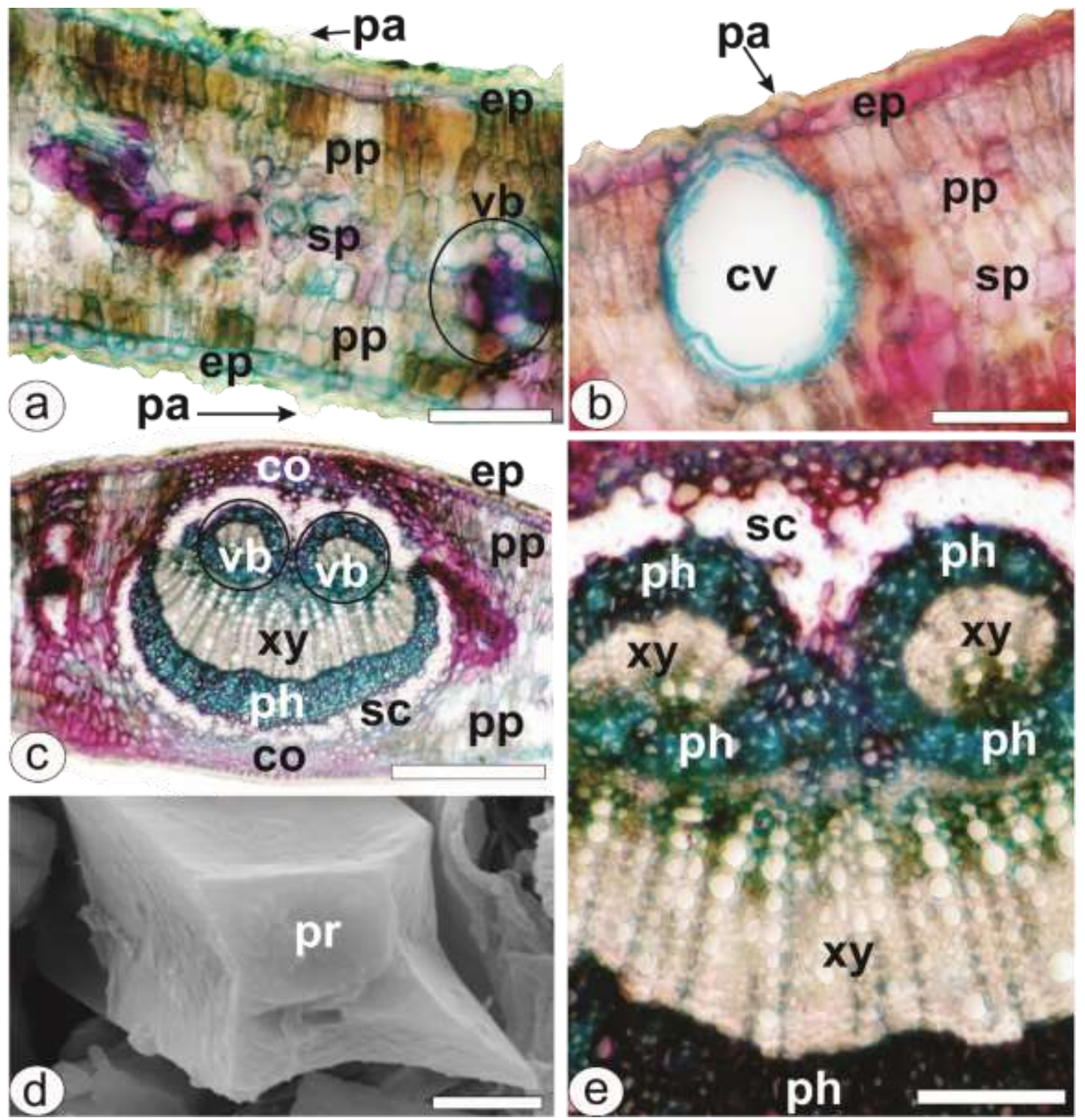

Figure 5. Leaf anatomy of Eucalyptus cinerea. [Light microscopy: a, b, c, e; FESEM: d]. a-c, e: Transverse sections (a, b: mesophyll; c, e: midrib) - stained in Astra blue/basic fuchsin. d: View of a prismatic crystal. [co- collenchyma, cvsecretory cavity, ep- epidermis, pa- papillae, ph- phloem, pp- palisade parenchyma, pr- prismatic crystal, scsclerenchymatous sheath, sp- spongy parenchyma, vb- vascular bundle, $x y-x y l e m$. Scale bars: $a, b, d, e=50 \mu \mathrm{m} ; \mathrm{c}=$ $200 \mu \mathrm{m}$.

The unilayered epidermis is covered by a thick and striated cuticle. The sub-epidermal collenchyma appeared as about 4 layers. Crystals were spread in the midrib as previously described for the mesophyll (Figure $5 \mathrm{D}$ ). The midrib stele consists of a large bicollateral vascular bundle in an open arc and two dorsal trace types. A similar arrangement was also found in E. benthamii, E. dunnii and E. globulus [69]. However, different patterns were observed in other species of Eucalyptus, such as collateral vascular bundle in an open arc with one dorsal plate in E. grandis [69] and a collateral vascular bundle in an open arc with invaginated ends in E. saligna [16]. The perivascular fiber cap adjoining the phloem (Figure $5 \mathrm{C}$, E) was also observed in E. badjensis, E. benthamii and E. dunnii [69]. Migacz and coauthors [69] reported that this feature could help in the identification of Eucalyptus species. 
The young stem is circular in cross-section (Figure $6 \mathrm{~A}$ ). The epidermis is uniseriate and covered by a thick and striated cuticle. Different stem shapes can be found in Eucalyptus, such as rectangular in E. grandis, circular in E. urophylla [74] and E. saligna [16] and stellate near the shoot apex and rectangular in developed stem in E. grandis [75]. Beneath the epidermis, cortical parenchyma has about 16 layers and there are some secretory cavities (Figure $6 \mathrm{~A}, \mathrm{~B}$ ), measuring $110 \mu \mathrm{m}$ in diameter on average. Secretory cavities in the stems of $E$. grandis, E. urophylla and E. saligna measure 78, 45 and 40-110 $\mu \mathrm{m}$ in diameter, respectively [16,74]. The vascular cylinders in $>2 \mathrm{~mm}$ wide stems present cambia forming phloem outward and xylem inward. Sclerenchymatous cells are seen along the periphery of the vascular system (Figure $6 \mathrm{~A}, \mathrm{C}$ ). This characteristic is also observed in E. pilularis, E. tetrodonta F.Muell. and E. nitens (H.Deane \& Maiden) Maiden [75].
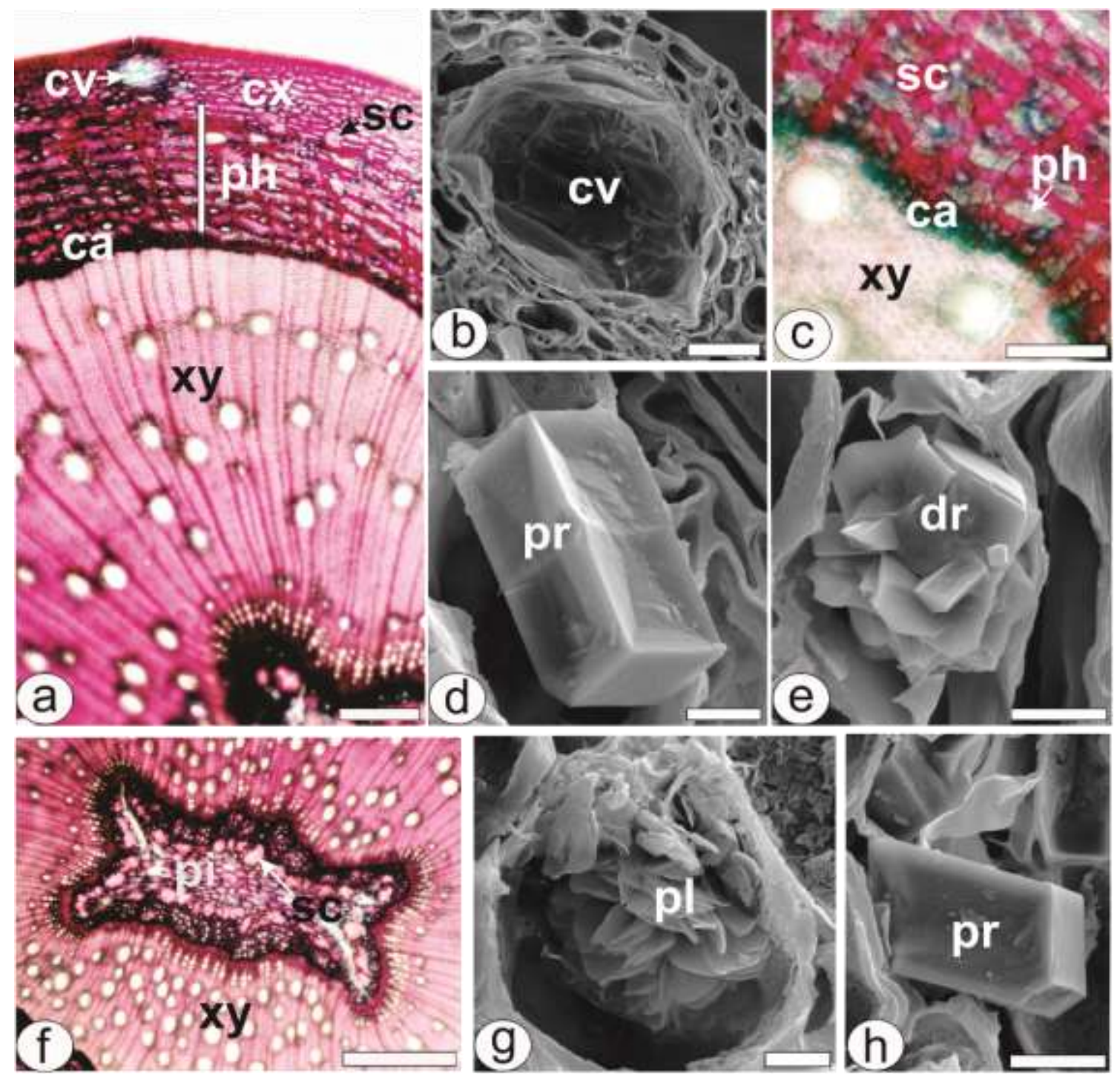

Figure 6. Stem anatomy of Eucalyptus cinerea. [Light microscopy stained in Astra blue/basic fuchsin: a, c, f; FESEM: $b, d, e, g, h]$. Transverse sections of stem (a- c, f), and views of crystals (d, e, g, h). [ca- cambia, cx- cortex, cocollenchyma, cv- secretory cavity, dr- a blocky and tabular crystal druse, ep- epidermis, ph- phloem, pi- pith, pl- platy aggregate cluster, pp- palisade parenchyma, pr- prismatic crystal, sc- sclerenchymatous sheath, $x y-x y l e m$. Scale bars: $a, f=100 \mu \mathrm{m}, \mathrm{c}=50 \mu \mathrm{m}, \mathrm{b}=20 \mu \mathrm{m}, \mathrm{h}=10 \mu \mathrm{m}, \mathrm{d}, \mathrm{e}, \mathrm{g}=5 \mu \mathrm{m}$.

The pith is arranged in a stellate shape in cross-section and is formed by parenchyma cells, thick-walled fibers, and crystal idioblasts (Figure $6 \mathrm{~F}$ ). Pith with different shapes was found in other species, such as rectangular in E. saligna [16], E. microcorys F.Muell., E. marginata Donn ex Sm. and E. grandis [75]. The shape of the vascular tissue can vary, depending on the age of the stem. For example, near the fourth node, E. camaldulensis, E. globulus and E. nitens showed rectangular or slightly stellate, whereas E. tetrodonta and E. pilularis presented rectangular or circular shapes.

In the present study, E. cinerea showed different morphotypes of crystals in the mesophyll, midrib and stem; these are prisms (Figure $6 \mathrm{D}, \mathrm{H}$ ), platy aggregate clusters (Figure $6 \mathrm{G}$ ), and blocky and tabular crystal 
druses (Figure $6 \mathrm{E}$ ). Several species detoxify soluble oxalic acid as insoluble calcium salts in their tissues. They can be prismatic crystals, druses, raphides, styloids or crystal sand and their shapes are important for diagnostic purposes $[28,76,77,78]$. Weiner and Dove [79] have reported that the excess of calcium is usually precipitated in calcium salts such as oxalate, carbonate, phosphate, silicate, sulfate, citrate and malate.

The three types of crystals were analyzed by EDS for their elemental composition and their spectra showed prominent peaks for calcium. The prisms in the midrib showed large peaks of calcium (24.29\%), carbon (56.75\%), and oxygen (18.97\%) (Figure $7 \mathrm{~A})$. The blocky and tabular druses evidenced large calcium $(50.00 \%)$, carbon $(19.80 \%)$, and oxygen $(30.21 \%)$ peaks (Figure $7 \mathrm{~B})$. The platy aggregation cluster showed large calcium (28.06\%), carbon (38.48\%), oxygen (29.48\%), and magnesium (3.98) peaks (Figure $7 \mathrm{C}$ ). The prisms in the stem indicated large calcium (26.72\%) and oxygen (73.28\%) peaks (Figure $7 \mathrm{D}$ ).

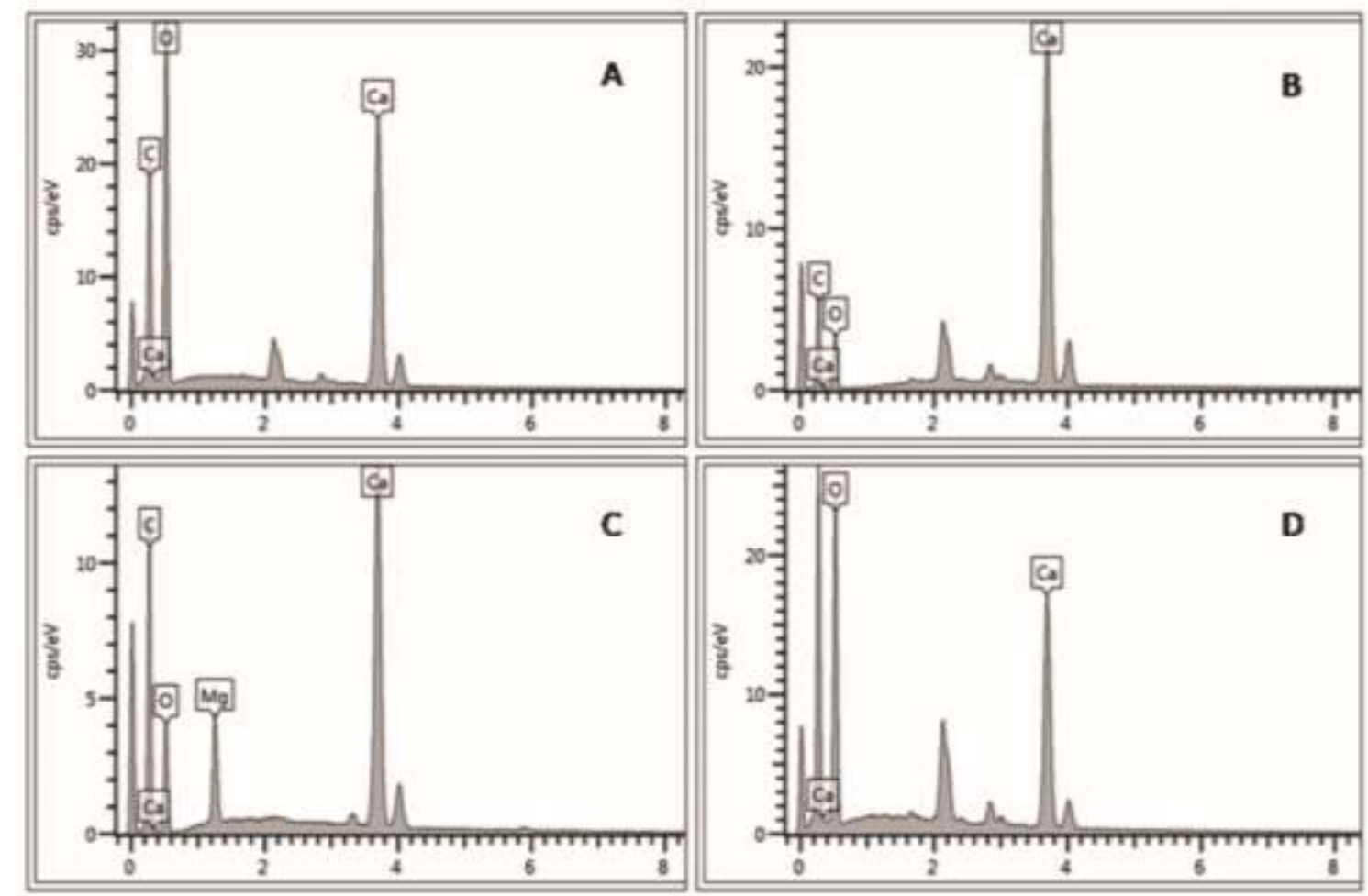

Figure 7. EDS (energy-dispersive X-ray spectroscopy) spectra of crystals of Eucalyptus cinerea. A. Prismatic crystal in the midrib; B. Blocky and tabular crystal druse; C. Platy aggregate cluster; D. Prismatic crystal in the stem. The major unlabeled peaks in these spectra represent gold $(\mathrm{Au})$, which was used to coat the samples.

\section{Histochemical Analysis}

The histochemical tests show the presence of lipophilic compounds in the cuticle in the leaf blade (Figure $8 \mathrm{~A}$ ), midrib (Figure $8 \mathrm{D}$ ) and stem. The secretory cavities also present volatile oils that reacted with Sudan III (Figure $8 \mathrm{D}$ ). Phenolic compounds reacted positively with ferric chloride and are found in the mesophyll (Figure $8 \mathrm{~B}$ ) and midrib phloem (Figure $8 \mathrm{C}$ ) in the leaves, cortex, phloem (Figure $8 \mathrm{~F}$ ) and xylem parenchyma in the stem (Figure $8 \mathrm{E}$ ). Small rounded starch grains are observed in the pith. Lignin is found in the vessels, tracheids and sclerenchyma cells present in the leaf midrib, stem cortex and pith.

Migacz and coauthors [69] observed phenolic compounds in the phloem in six species of Eucalyptus, but in higher amounts in E. grandis and E. saligna. Several idioblasts containing tannin were seen in the cortex in E. urophylla [74]. Eucalyptus saligna showed several calcium oxalate prisms, secretory cavities and phenolic idioblasts in the stem [16]. 


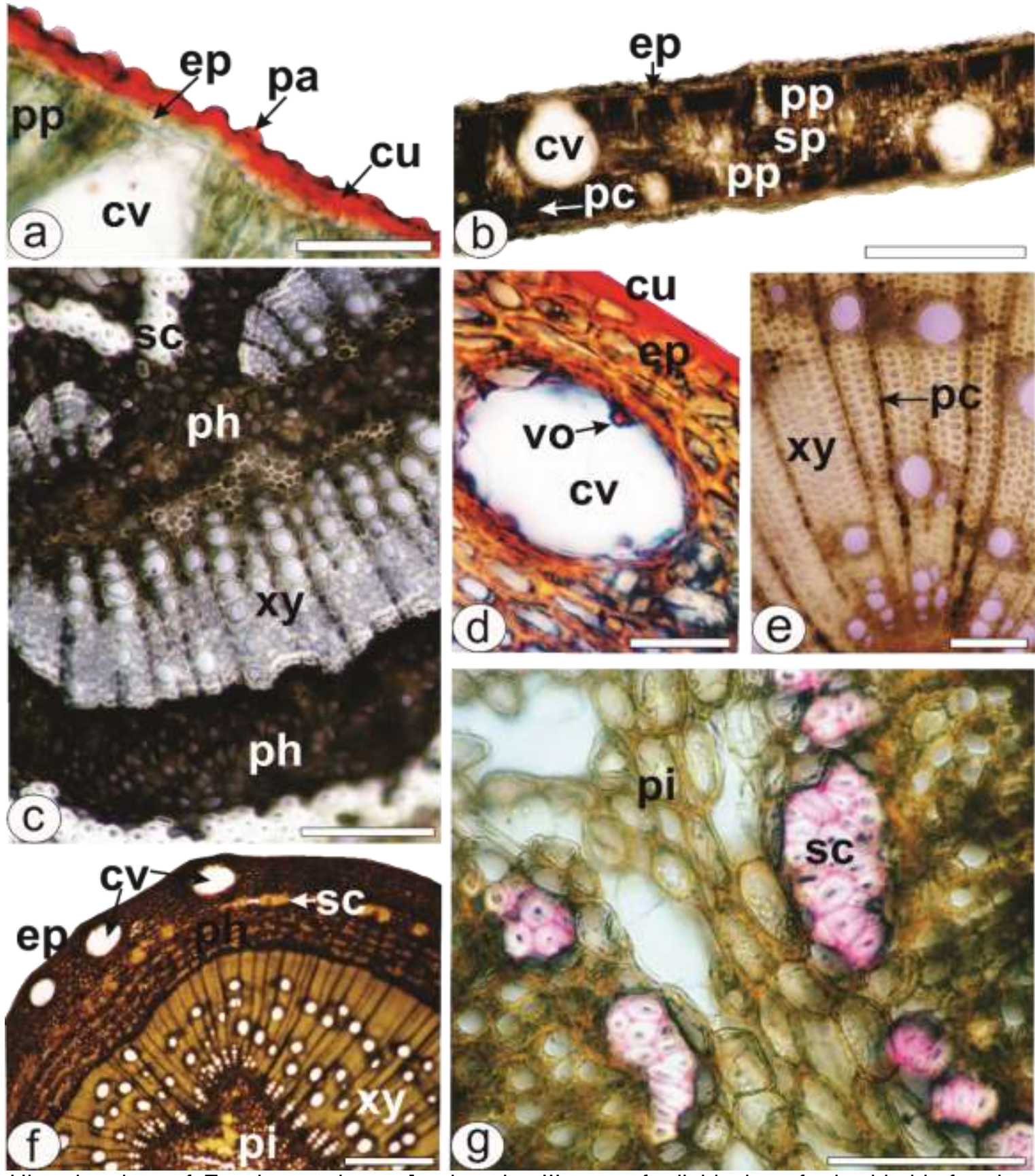

Figure 8. Histochemistry of Eucalyptus cinerea [a, d: sudan III to test for lipids; b, c: ferric chloride for phenolics; e, f: potassium dichromate solution (10\%) for phenolic compounds; g: phloroglucinol/HCl for lignin. Transverse sections - ac: leaf; d-g: stem [co: collenchyma, cx- cortex, cu: cuticle, cv: secretory cavities, en: endodermis, eo: essential oil, ep: epidermis, gp: ground parenchyma, pc: phenolic compounds, ph: phloem, pi: pith, pr: prismatic crystal, sc: sclerenchyma, sg: starch grains, sp- spongy parenchyma, pp- palisade parenchyma, vo- volatile oil, $x y: x y l e m]$. Scale bar: $b, f=200 \mu \mathrm{m} ; \mathrm{a}, \mathrm{c}, \mathrm{e}, \mathrm{g}=50 \mu \mathrm{m} ; \mathrm{d}=20 \mu \mathrm{m}$.

\section{CONCLUSION}

The present study has demonstrated the antioxidant, antimicrobial and cytotoxic activities. It also explores the chemical composition of EOs and anatomical characters of the leaves and stems of Eucalyptus cinerea cultivated in Brazil. The main constituent of the EO was 1,8-cineole (55.24\%). The EO presented low antioxidant activity in the three methods tested. In the microbiological test, the best results were against $C$. albicans and S. pyogenes with MIC of $0.104 \mathrm{mg} / \mathrm{mL}$. The EO reduced the viability of the Jurkat cells $\left(\mathrm{IC}_{50}\right.$ $391.43 \mu \mathrm{g} / \mathrm{mL}$ ) and Calu-3 cells ( $\mathrm{IC}_{50} 689.79 \mu \mathrm{g} / \mathrm{mL}$ ) by the MTT assay, decreased DNA content in the Jurkat cells after $72 \mathrm{~h}$ of treatment and finally increased the percentage of cells in the sub G0 and S phases with concomitant reduction of the cell percentage in the G0/G1 and G2/M phases and caused DNA fragmentation of $29.73 \%$. These results indicate that the EO has possibly lead to a death mechanism associated with apoptosis. 
The anatomical features that could help in the identification $E$. cinerea include: isobilateral and amphistomatic leaves; epidermis with papillae, anomocytic and actinocytic stomata; slightly biconvex midrib with one large bicollateral vascular bundle in open arc and two smaller dorsal bundles; circular stems; sclerenchyma in the cortex and pith; and prisms, platy aggregate clusters and blocky and tabular crystal druses in the mesophyll, midrib and stem. Histochemical tests revealed the presence of lipophilic and phenolic compounds, lignified elements and starch grains.

Acknowledgments: Authors would like to thank CAPEs - Coordenação de Aperfeiçoamento de Pessoal de Nível Superior (scholarship code-001) and C-LABMU at the State University of Ponta Grossa for the scanning electron micrographs and energy-dispersive $\mathrm{X}$-ray spectroscopy.

Conflicts of Interest: The authors declare no conflict of interest. The funders had no role in the design of the study, collection, analyses and interpretation of data, writing of the manuscript, or in the decision to publish the results.

\section{REFERENCES}

1. Flores TB, Alvares CA, Souza VC, Stape JL. Eucalyptus in Brazil: climatic zoning and identification guide. Piracicaba: IPEF; 2018.

2. Barbosa LCA, Filomeno CA, Teixeira RR. Chemical variability and biological activities of Eucalyptus spp. volatile oils. Molecules. 2016 Dec;21(12):1671. doi:10.3390/molecules21121671.

3. Salehi B, Sharifi-Rad J, Quispe C, Llaique H, Villalobos M, Smeriglio A, Trombetta D, Ezzat SM, Salem MA, Zayed A, Castillo CMS, Yazdi SE, Sen S, Acharya K, Sharopov F, Martins N. Insights into Eucalyptus genus chemical constituents, biological activities and health-promoting effects. Trends Food Sci Technol. 2019 Sep;91:609-24. doi:10.1016/j.tifs.2019.08.003.

4. Cimanga K, Kambu K, Tona L, Apers S, De Bruyne T, Hermans N, Totté J, Pieters L, Vlietinck AJ. Correlation between chemical composition and antibacterial activity of essential oils of some aromatic medicinal plants growing in the Democratic Republic of Congo. J Ethnopharmacol. 2002 Feb;79(2):213-20. doi:10.1016/S03788741(01)00384-1.

5. Döll-Boscardin PM, Sartoratto A, Maia BHLNS, Paula JP, Nakashima T, Farago PV, Kanunfre CC. In Vitro Cytotoxic Potential of Essential Oils of Eucalyptus benthamii and Its Related Terpenes on Tumor Cell Lines. Evid Based Complement Alternat Med. 2012 May;342652:1-8. doi:10.1155/2012/342652.

6. Döll-Boscardin PM, Borsato DM, Mirante DC, Nakashima T, Budel JM, Kovaliczn RA, Maia BHLNS, Paula JP, Farago PV. Essential oil from leaves of Eucalyptus benthamii: Secretory structures, volatile composition and biological activities. Planta Medica. 2015 Jun;81(11):1823-9. doi:10.1055/s-0035-1556210.

7. Indústria Brasileira de Árvores (IBA). Relatório 2017 [Internet]. [place unknown: publisher: unknown]; [updated 2019 Jul 17; cited 2019 Jul 17] Available from: https://www.iba.org/datafiles/publicacoes/pdf/ibarelatorioanual2017.pdf.

8. Levison KK, Takayama K, Isowa K, Okabe K, Nagai T. Formulation optimization of indomethacin gels containing a combination of three kinds of cyclic monoterpenes as percutaneous penetration enhancers. J Pharm Sci. 1994 Sep;83(9):1367-72. doi:10.1002/jps.2600830932.

9. Franco J, Nakashima T, Franco L, Boller C. Composição química e atividade antimicrobiana in vitro do óleo essencial de Eucalyptus cinerea F. Mull. ex Benth., Myrtaceae, extraído em diferentes intervalos de tempo. Braz J Pharmacog. 2005 Set;15(3):191-4. doi:10.1590/S0102-695X2005000300004.

10. Sebei K, Sakouhi F, Herchi W, Khouja ML, Boukhchina S. Chemical composition and antibacterial activities of seven Eucalyptus species essential oils leaves. Biol Res. 2015 Jan;48(7):1-5. doi:10.1186/0717-6287-48-7.

11. Babu GDK, Singh B. Simulation of Eucalyptus cinerea oil distillation: A study on optimization of 1,8-cineole production. Biochem Eng J. 2009 May;44(2-3):226-31. doi:10.1016/j.bej.2008.12.012.

12. Chippendale GM. Flora of Australia, Volume 19, Myrtaceae-Eucalyptus, Angophora. Canberra: Australian Government Publishing Service; 1988. 542 p.

13. Hill KD, Johnson LAS. New taxa and combinations in Eucalyptus and Angophora (Myrtaceae). Sydney: National Herbarium of New South Wales; 1990. 108 p.

14. Boland DJ, Brooker MIH, Chippendale GM, Hall N, Hyland BPM, Johnston RD, Kleinig DA, McDonald MW, Turner JD. Forest Trees of Australia. 5th ed. Melbourne: CSIRO Publishing; 2006. 768 p.

15. Budel JM, Wang M, Raman V, Zhao J, Khan SI, Rehman JU, Techen N, Tekwani B, Monteiro LM, Heiden G, Takeda IJM, Farago PV, Khan IA. Essential Oils of Five Baccharis Species: Investigations on the Chemical Composition and Biological Activities. Molecules. 2018 Oct;23(10):2620. doi:10.3390/molecules23102620. 
16. Saulle CC, Raman V, Oliveira AVG, Maia BHLNS, Meneguetti EK, Flores TB, Farago PV, Khan IA, Budel JM. Anatomy and volatile oil chemistry of Eucalyptus saligna cultivated in South Brazil. Braz J Pharm. 2018 Apr;28(2):125-34. doi:10.1016/j.bjp.2018.03.001.

17. Yen G, Wu J. Antioxidant and radical scavenging properties of extracts from Ganoderma tsugae. Food Chem. 1999 May;65(3):375-9. doi:10.1016/S0308-8146(98)00239-8.

18. Chen CN, Wu CL, Shy HS, Lin JK. Cytotoxic prenylflavanones from Taiwanese Propolis. J Nat Prod. 2003 Mar;66(4): 503-6. doi:10.1021/np0203180.

19. Re R, Pellegrini N, Proteggente A, Pannala A, Yang M, Rice-Evans C. Antioxidant activity applying an improved ABTS radical cation decolorization assay. Free Radic Biol Med. 1999 May;26(9-10):1231-7. doi:10.1016/S08915849(98)00315-3.

20. Prieto P, Pineda M, Aguilar M. Spectrophotometric Quantitation of Antioxidant Capacity through the Formation of a Phosphomolybdenum Complex: Specific Application to the Determination of Vitamin E. Anal Biochem. 1999 May;269(2):337-41. doi:10.1006/abio.1999.4019.

21. National Committee for Clinical Laboratory Standards (NCCLS). Metodologia dos Testes de Sensibilidade a Agentes Antimicrobianos por diluição para Bactérias de Crescimento Aeróbico [Internet]. [place unknown: EUA publisher: NCCLS]; [updated 2003 Jan 01; cited 2019 Jul 17] Available from: http://www.anvisa.gov.br/servicosaude/manuais/clsi/clsi_opasm7_a6.pdf.

22. Virador VM, Kobayashi N, Matsunaga J, Hearing VJ. A standardized protocol for assessing regulators of pigmentation. Anal Biochem. 1999 Jun;270(2):207-19. doi:10.1006/abio.1999.4090.

23. Sylvestre M, Pichette A, Longtin A, Nagau F, Legault J. Essential oil analysis and anticancer activity of leaf essential oil of Croton flavens L. from Guadeloupe. J Ethnopharmacol. 2006 Jan;103(1):99-102. doi:10.1016/j.jep.2005.07.011.

24. Cardile V, Russo A, Formisano C, Rigano D, Senatore F, Arnold NA, Piozzi F. Essential oils of Salvia bracteata and Salvia rubifolia from Lebanon: chemical composition, antimicrobial activity and inhibitory effect on human melanoma cells. J Ethnopharmacol. 2009 Nov;126(2):265-72. doi:10.1016/j.jep.2009.08.034.

25. Seal S, Chatterjee P, Bhattacharya S, Pal D, Dasgupta S, Kundu R, Mukherjee S, Bhattacharya S, Bhuyan M, Bhattacharya PR, Baishya G, Barua NC, Baruah PK, Rao PG, Bhattacharya S. Vapor of volatile oils from Litsea cubeba seed induces apoptosis and causes cell cycle arrest in lung cancer cells. PLoS ONE. 2012 Oct;7(10):e47014. doi:10.1371/journal.pone.0047014.

26. Dengler WA, Schulte J, Berger DP, Mertelsmann R, Fiebig HH. Development of a propidium iodide fluorescence assay for proliferation and cytotoxicity assays. Anticancer Drugs. $1995 \mathrm{Jul} ; 6(4): 522-32$. doi:10.1097/00001813199508000-00005.

27. Crissman HA, Steinkamp JA. Rapid simultaneous measurement of DNA, protein and cell volume in single cells from large mammalian cell populations. J Cell Biol. 1973 Dec;59(3):766-71. doi:10.1083/jcb.59.3.766.

28. Machado CD, Raman V, Rehman JU, Maia BHLNS, Meneghetti EK, Almeida VP, Silva RZ, Farago PV, Khan IA, Budel JM. Schinus molle: anatomy of leaves and stems, chemical composition and insecticidal activities of volatile oil against bed bug (Cimex lectularius). Braz J Pharmacogn. 2019 Feb;29(1):1-10. doi:10.1016/j.bjp.2018.10.005.

29. Lucia A, Licastro S, Zerba E, Audino PG, Masuh H. Sensitivity of Aedes aegypti adults (Diptera: Culicidae) to the vapors of Eucalyptus essential oils. Bioresour Technol. 2009 Dec;100(23):6083-7. doi:10.1016/j.biortech.2009.02.075.

30. Soliman FM, Fathy MM, Salama MM, Saber FR. Chemical composition and bioactivity of the volatile oil from leaves and stems of Eucalyptus cinerea. Pharm Biol. 2014 Jul;52(10):1272-7. doi:10.3109/13880209.2014.889177.

31. Guenther E. The Essential Oils: The constituents of essential oils. 3rd ed. New York: D. Van Nostrand; 1957.

32. Saeed MA, Sabir AW. Antimicrobial studies of the constituents of Pakistani Eucalyptus oils. J Fac Pharm Gazi Univ. 1995;12:129-40.

33. Juergens UR, Dethlefsen U, Steinkamp G, Gillissen A, Repges R, Vetter H. Anti-inflammatory activity of 1.8-cineol (eucalyptol) in bronchial asthma: a double-blind placebo-controlled trial. Respir Med. 2003 Mar;97(3):250-6. doi:10.1053/rmed.2003.1432.

34. Vitti AMS, Brito JO. Eucalyptus essential oil. 17th ed. São Paulo: USP/ESALQ; 2003.

35. Bugarin D, Grbovic S, Orčič D, Mitić-Ćulafić D, Knežević-Vukčević J, Mimica-Dukić N. Essential Oil of Eucalyptus gunnii Hook. as a novel source of antioxidant, antimutagenic and antibacterial agents. Molecules. 2014 Nov;19(11):19007-20. doi:10.3390/molecules191119007.

36. Silvestre AJD, Cavaleiro JAS, Delmond B, Filliatre C, Bourgeois G. Analysis of the variation of the essential oil composition of Eucalyptus globulus Labill. from Portugal using multivariate statistical analysis. Ind Crops Prod. 1997 Feb;6(1):27-33. doi:10.1016/S0926-6690(96)00200-2. 
37. Viturro $\mathrm{Cl}$, Molina AC, Heit Cl. Volatile components of Eucalyptus globulus Labill ssp. bicostata from Jujuy, Argentina. J Essent Oil Res. 2003 Dec;15(3):206-8. doi:10.1080/10412905.2003.9712115.

38. Seigler DS. Monoterpenes. In: Seigler DS, editor. Plant Secondary Metabolism. London: Kluwer Academic Publishers; 1998. p. 324-352.

39. Beier RC, Nigg HN. Natural toxicants in foods. In: Nigg HN, Seigler DS, editors. Phytochemical Resources for Medicine and Agriculture. New York: Plenum Press; 1992. p. 272-292.

40. Adams RP. Identification of Essential Oil Components by Gas Chromatography/Mass Spectroscopy. 4th ed. Illinois: Carol Stream; 2007. 804 p.

41. Bhavanani SM, Balow CH. New agents for Gram-positive bacteria. Curr Opin Microbiol. 2000 Oct;3(5):528-34. doi:10.1016/S1369-5274(00)00134-X.

42. Agarwal V, Lal P, Pruthi V. Prevention of Candida albicans biofilm by plant oils. Mycopathologia. 2007 Oct;165:139. doi:10.1007/s11046-007-9077-9.

43. Marzoug HNB, Romdhane M, Lebrihi A, Mathieu F, Couderc F, Abderraba M, Khouja ML, Bouajila J. Eucalyptus oleosa essential oils: chemical composition and antimicrobial and antioxidant activities of the oils from different plant parts (stems, leaves, flowers and fruits). Molecules. 2011 Feb;16(2):1695-709. doi:10.3390/molecules16021695.

44. Burt S. Essential oils: their antibacterial properties and potential applications in foods-a review. Int J Food Microbiol. 2004 Aug;94(3):223-53. doi:10.1016/j.ijfoodmicro.2004.03.022.

45. Ennajar M, Bouajila J, Lebrihi A, Mathieu F, Abderraba M, Raies A, Romdhane M. Chemical composition and antimicrobial and antioxidant activities of essential oils and various extracts of Juniperus phoenicea $\mathrm{L}$. (Cupressacees). J Food Sci. 2009 Sep;74(7):364-71. doi:10.1111/j.1750-3841.2009.01277.x.

46. Silva SM, Abe SY, Murakami FS, Frensch G, Marques FA, Nakashima T. Essential oils from different plant parts of Eucalyptus cinerea F. Muell. ex Benth. (Myrtaceae) as a source of 1,8-cineole and their bioactivities. Pharm. 2011 Nov;4(12):1535-50. doi:10.3390/ph4121535.

47. Hammer KA, Carson CF, Riley TV. Antimicrobial activity of essential oils and other plant extracts. J. Appl. Microbiol. 1999 Jun;86(6):985-90. doi:10.1046/j.1365-2672.1999.00780.x.

48. Gobbo-Neto L, Lopes NP. Medicinal plants: factors influencing the content of secondary metabolites. Quím Nova. 2007 Abr;30(2):374-81. doi:10.1590/S0100-40422007000200026.

49. Bendaoud H, Bouajila J, Rhouma A, Savagnac A, Romdhane M. GC/MS analysis and antimicrobial and antioxidant activities of essential oil of Eucalyptus radiata. J Sci Food Agric. 2009 Apr;89(8):1292-7. doi:10.1002/jsfa.3585.

50. Salem MZM, Ashmawy NA, Elansary HO, El-Settawy AA. Chemotyping of diverse Eucalyptus species grown in Egypt and antioxidant and antibacterial activities of its respective essential oils. Nat Prod Res. 2014 Nov;29(7):6815. doi:10.1080/14786419.2014.981539.

51. Ruberto G, Baratta MT. Antioxidant activity of selected essential oil components in two lipid model systems. Food Chem. 2000 May;69(2):167-74. doi:10.1016/S0308-8146(99)00247-2.

52. Ashour HM. Antibacterial, antifungal, and anticancer activities of volatile oils and extracts from stems, leaves, and flowers of Eucalyptus sideroxylon and Eucalyptus torquata. Cancer Biol Ther. 2008 Mar;7(3):399-403. doi:10.4161/cbt.7.3.5367.

53. Silva SL, Figueiredo PM, Yano T. Cytotoxic evaluation of essential oil from Zanthoxylum rhoifolium Lam. leaves. Acta Amaz. 2007 Jun;37(2):281-5. doi:10.1590/S0044-59672007000200015.

54. Grecco SS, Martins EGA, Girola N, Figueiredo CR, Matsuo AL, Soares MG, Bertoldo BC, Sartorelli P, Lago JHG. Chemical composition and in vitro cytotoxic effects of the essential oil from Nectandra leucantha leaves. Pharm Biol. 2014 Oct;53(1):133-7. doi:10.3109/13880209.2014.912238.

55. Murata S, Shiragami R, Kosugi C, Tezuka T, Yamazaki M, Hirano A, Yoshimura Y, Suzuki M, Shuto K, Ohkohchi N, Koda K. Antitumor effect of 1,8-cineole against colon cancer. Oncol Rep. 2013 Oct;30(6):2647-52. doi:10.3892/or.2013.2763.

56. Mubarak EE, Ali LZ, Ahmed IFA, Ahmed ABA, Taha RM. Essential Oil Compositions and Cytotoxicity from various organs of Eucalyptus camaldulensis. Int J Agric Biol. 2015 Jan;17(2):320-6.

57. Pereira CB, Kanunfre CC, Farago PV, Borsato DM, Budel JM, Maia BHLNS, Campesatto EA, Sartoratto A, Miguel MD, Miguel OG. Cytotoxic mechanism of Baccharis milleflora (Less.) DC. essential oil. Toxicol in Vitro. 2017 Aug;42:214-221. doi:10.1016/j.tiv.2017.04.031.

58. Selvarani $\mathrm{V}$, James $\mathrm{H}$. The activity of cedar leaf oil vapor against respiratory viruses: practical applications. J Appl Pharm Sci. 2013 Nov;3(11):11-5. doi:10.7324/JAPS.2013.31103.

59. Ong HX, Traini D, Bebawy M, Young PM. Ciprofloxacin Is Actively Transported across Bronchial Lung Epithelial Cells Using a Calu-3 Air Interface Cell Model. Antimicrob Agents Chemother. 2013 Jun;57(6):2535-40. doi:10.1128/AAC.00306-13. 
60. Laird K, Phillips C. Vapour phase: a potential future use for essential oils as antimicrobials?, Lett Appl Microbiol. 2012 Mar;54(3):169-74. doi:10.1111/j.1472-765X.2011.03190.x.

61. Jakiemiu EAR. Uma contribuição ao estudo do óleo essencial e do extrado de tomilho (Thymus vulgaris L.) [dissertation], Curitiba (PR): Universidade Federal do Paraná; 2008.

62. Bayala B, Bassole IHN, Scifo R, Gnoula C, Morel L, Lobaccaro JA, Simpore J. Anticancer activity of essential oils and their chemical components - a review. Am J Cancer Res. 2014 Nov;4(6):591-607.

63. Manjamalai A, Kumar MJM, Grace VMB. Essential oil of Tridax procumbens $L$ induces apoptosis and suppresses angiogenesis and lung metastasis of the B16F-10 cell line in C57BL/6 mice. Asian Pac J Cancer Prev. 2012 Nov;13(11):5887-95. doi:10.7314/APJCP.2012.13.11.5887.

64. Grivicich I, Regner A, Rocha AB. Morte Celular por Apoptose. Rev Bras Cancerol. 2007 Jan;53(3):335-43.

65. Wong RSY. Apoptosis in cancer: from pathogenesis to treatment. J Exp Clin Cancer Res. 2011 Sep;30(87):1-14. doi:10.1186/1756-9966-30-87.

66. Gautam N, Mantha AK, Mittal S. Essential Oils and Their Constituents as Anticancer Agents: A Mechanistic View. Biomed Res Int. 2014 Jun;154106:1-23. doi:10.1155/2014/154106.

67. Russo GL, Russo M, Spagnuolo C, Tedesco I, Bilotto S, lannitti R, Palumbo R. Quercetin: a pleiotropic kinase inhibitor against cancer. Cancer Treat Res. 2014 Jan;159:185-205. doi:10.1007/978-3-642-38007-5_11.

68. Justus B, Kanunfre CC, Budel JM, Faria MF, Raman V, Paula JP, Farago PV. New insights into the mechanisms of French lavender essential oil on non-small-cell lung cancer cell growth. Ind Crop Prod. 2019 Sep;136:28-36. doi:10.1016/j.indcrop.2019.04.051.

69. Migacz IP, Raeski PA, Almeida VP, Raman V, Nisgoski S, Muniz GIB, Farago PV, Khan IA, Budel JM. Comparative leaf morpho-anatomy of six species of Eucalyptus cultivated in Brazil. Braz J Pharmacogn. 2018 Jun;28(3):27381. doi:10.1016/j.bjp.2018.04.006.

70. Malinowski LRL, Nakashima T, Alquini Y. Caracterização morfoanatômica das folhas jovens de Eucalyptus globulus Labill ssp. bicostata (Maiden et al.) J.B. Kirkpat. (Myrtaceae). Lat Am J Pharm. 2009 Jun;28(5):756-61.

71. Santos LDT, Thadeo M, larema L, Meira RMSA, Ferreira FA. Foliar anatomy and histochemistry in seven species of Eucalyptus. Rev Árvore. 2008 Aug;32(4):769-79. doi:10.1590/S0100-67622008000400019.

72. Retamales HA, Scharaschkin T. Comparative leaf anatomy and micromorphology of the Chilean Myrtaceae: Taxonomic and ecological implications. Flora. 2015 Nov;217:138-54. doi:10.1016/j.flora.2015.10.005.

73. Knight TG, Wallwork MAB, Sedgley M. Leaf epicuticular wax and cuticle ultrastructure of four Eucalyptus species and their hybrids. Int J Plant Sci. 2004 Jan;165(1):27-36. doi:10.1086/380744.

74. Brisola SH, Demarco D. Stem anatomical analysis of Eucalyptus grandis, E. urophylla and E. grandis $\times$ urophylla: wood development and its industrial importance. Sci For. 2011 Sep;39(91):317-30. doi:20113374625.

75. Bryant PH, Trueman SJ. Stem anatomy and adventitious root formation in cuttings of Angophora, Corymbia and Eucalyptus. Forests. 2015 Apr;6(4):1227-38. doi:10.3390/f6041227.

76. Almeida VP, Raman V, Raeski PA, Urban AM, Swiech JN, Miguel MD, Farago PV, Khan IA, Budel JM. Anatomy, micromorphology, and histochemistry of leaves and stems of Cantinoa althaeifolia (Lamiaceae). Microsc Res Techniq. 2020 May;83(5):551-7. doi:10.1002/jemt.23444.

77. D'Almeida W, Monteiro LM, Raman V, Rehman JU, Paludo KS, Maia, BHLNS. Casapula I, Khan IA, Farago PV, Budel JM. Microscopy of Eugenia involucrata, Chemical Composition and Biological Activities of the Volatile Oil. Braz J Pharmacogn. 2021 Mar. doi: 10.1007/s43450-020-00123-4.

78. Brustulim, LJR; Paludo, KS; Monteiro, LM; Raman, V; Maia, BHLNS; Casapula, I; Rehman, JR; Khan, IA; Farago, PV; Budel, JM. Ocotea porosa: anatomy and histochemistry of leaves and stems, chemical composition, cytotoxicity and insecticidal activities of essential oil. Braz Arch. Biol Technol. 2020 Ago; 63: e20190082. doi:10.1590/1678-4324-2020190082

79. Weiner S, Dove PM. An overview of biomineralization processes and the problem of the vital effect. Rev Mineral Geochem. 2003 Jan;54(1):1-29. doi:10.2113/0540001.

2021 by the authors. Submitted for possible open access publication under the terms and conditions of the Creative Commons Attribution (CC BY NC) license (https://creativecommons.org/licenses/by-nc/4.0/). 